\begin{tabular}{l} 
Geologia Croatica \\
\hline $62 / 2$
\end{tabular}

\begin{abstract}
Velika Palagruža (Pelagosa) is the largest island of the Palagruža archipelago (central Adriatic Sea, Croatia). Despite its minute size the island bears a certain geological interest being the only exposed piece of land in the central part (Mid-Adriatic ridge) of the common Adriatic foreland of the Apenninic and the Dinaridic orogenic domains. The litho-, bio-, and chemostratigraphic (strontium and sulphur isotopes) characteristics of the sedimentary units, along with tectono-structural and geomorphic characteristics of the island, are described in this paper. The oldest Žalo unit is composed of highly deformed siliciclastics containing gypsum, and carbonates of Middle Triassic (Ladinian) age. This unit represents a transitional fluvial-to-shallow marine, occasionally evaporitic environment, typical of the Middle Triassic rifting phase of the Adriatic microplate. Soft and strongly deformed Žalo unit deposits are found along a probably still active, WNW-ESE striking, subvertical, oblique-slip fault that crosses the entire length of the island. The Žalo unit is probably in diapiric contact with the Lanterna unit, poorly defined as Late Triassic, and characterized by dolomite with chert and dolomite breccia, presumably deposited in a transitional platform-to-basin environment of an evolving Adriatic basin. The Lanterna unit deposits are capped by Miocene biocalcarenites of the Salamandrija unit over an almost perpendicular discordance, possibly representing an unconformity, suggesting that an early deformational phase preceded a Miocene marine transgression. Talus, landslide deposits, and humic soil make up the cover of the bedrock sedimentary succession, and they represent the ultimate phase of emersion of the island, which probably occurred during Pliocene(?) to Quaternary times. An active neotectonic regime of the central Adriatic is evidenced by present-day seismicity, while recent uplifting of the island is shown by the presence of remnants of pebbly palaeobeach deposits, marine (erosional) straths, and cyanobacterial supratidal encrustations (pelagosite) currently observed at various elevations above mean sea level.
\end{abstract}

Keywords: carbonate platform, basin, Triassic, Neogene, Mid-Adriatic ridge, recent uplift 


\section{INTRODUCTION AND PREVIOUS WORK}

Velika Palagruža (Pelagosa in Italian) is a small island in the central Adriatic Sea, the largest within the Palagruža archipelago (Fig. 1). The island is placed within the common Adriatic foreland of the Apennines and the Dinarides, $57 \mathrm{~km}$ from the Gargano promontory to the south, and $60 \mathrm{~km}$ from the Island of Lastovo to the northeast. The distance from the mainland as well as steep slopes and a hostile rocky coast, makes access to the island rather difficult. A handful of published studies be counted since the first geological and palaeontological reconnaissance of the island of Palagruža was carried out by STUR (1874), at about the time when the Austrians were building the monumental lighthouse on the highest point of the island. Palagruža was then revisited by STACHE (1876) and, independently, by MARCHESETTI (1876).

Further geological studies were carried out by BOŽIČEVIĆ et al. (1965). The authors proposed a Middle Jurassic age for the basal dolomite formation based on the presence of Lithothamnion, and a Miocene age for the biocalcarenitic limestone at the top of the succession, according to the foraminiferal and mollusc association. The stratigraphic bedrock succession of Velika Palagruža is capped by Pliocene(?) to Quaternary talus breccias and humic soil.

The authors of the explanatory notes for the basic geological map sheet (KOROLIJA et al., 1977) proposed a Jurassic age for a siliciclastic unit with gypsum exposed near the beach of Žalo (see Fig. 2 for location), based on a general lithological analogy with the Komiža complex on the island of Vis (at the time considered to be of Jurassic age), and stratigraphic relationships with the underlying dolomites containing chert nodules of proposed Late Jurassic age. KOROLIJA et al. (1977) argued for the Late Cretaceous age of the overlying biocalcarenites exposed in a quarry pit at Salamandija (see Fig. 2 for location).

SOKAČ et al. (1980) identified the foraminifera Meandrospira pusilla from a small outcrop of siliciclastic-evaporitic rocks near Žalo containing sandstones, gypsum, clay, and silt, which, along with results from mineralogical analy- ses, indicated an Early Triassic or possibly even older (Late Permian) age. The authors, in agreement with the interpretation of KOROLIJA et al. (1977), viewed this siliciclasticevaporitic unit at Žalo as a diapir. The diapiric setting of the Palagruža block was suggested by GRANDIĆ et al. (2002) following seismo-stratigraphic interpretation. GRANDIĆ et al. (2002) also referred the broader area of the Palagruža archipelago to the Jurassic to Palaeogene Adriatic basin domain.

Gypsum often occurs in Upper Permian to Triassic formations throughout the Alpine domain, and represents shallow water evaporitic environments during an early subsidence phase of the Adriatic microplate, which was probably attached to the African continental crust (e.g. CHANNELL et al., 1979; BOSELLINI, 2002). However, the stratigraphic position of Adriatic evaporites and associated rocks is often doubtful, mainly due to their chaotic setting.

From the few geologic reports cited above it appears that Palagruža has a geological complexity and overall importance much bigger that its own minute size, which definitively demands more detailed study. The results of a preliminary geological survey are reported here, which highlights the stratigraphic and structural complexity of this island. While some uncertainties still remain in the accurate chronostratigraphic assessment of the main rock formations, structural and geomorphic features exposed in the island offer new evidence for a past and recent history of geodynamic events.

\section{REGIONAL GEOLOGICAL AND TECTONIC SETTINGS}

Palaeogeographically, the central Adriatic area is considered to represent a Jurassic to Palaeogene Adriatic basin enclosed between the Apulia carbonate platform to the southwest (Italy), and the Adriatic (Dalmatian) carbonate platform to the northeast (Croatia) (ZAPPATERRA, 1994; BOSELLINI, 2002; GRANDIĆ et al., 2002; TARI, 2002; VLAHOVIĆ et al., 2005). At present, the succession of mostly pelagic for-
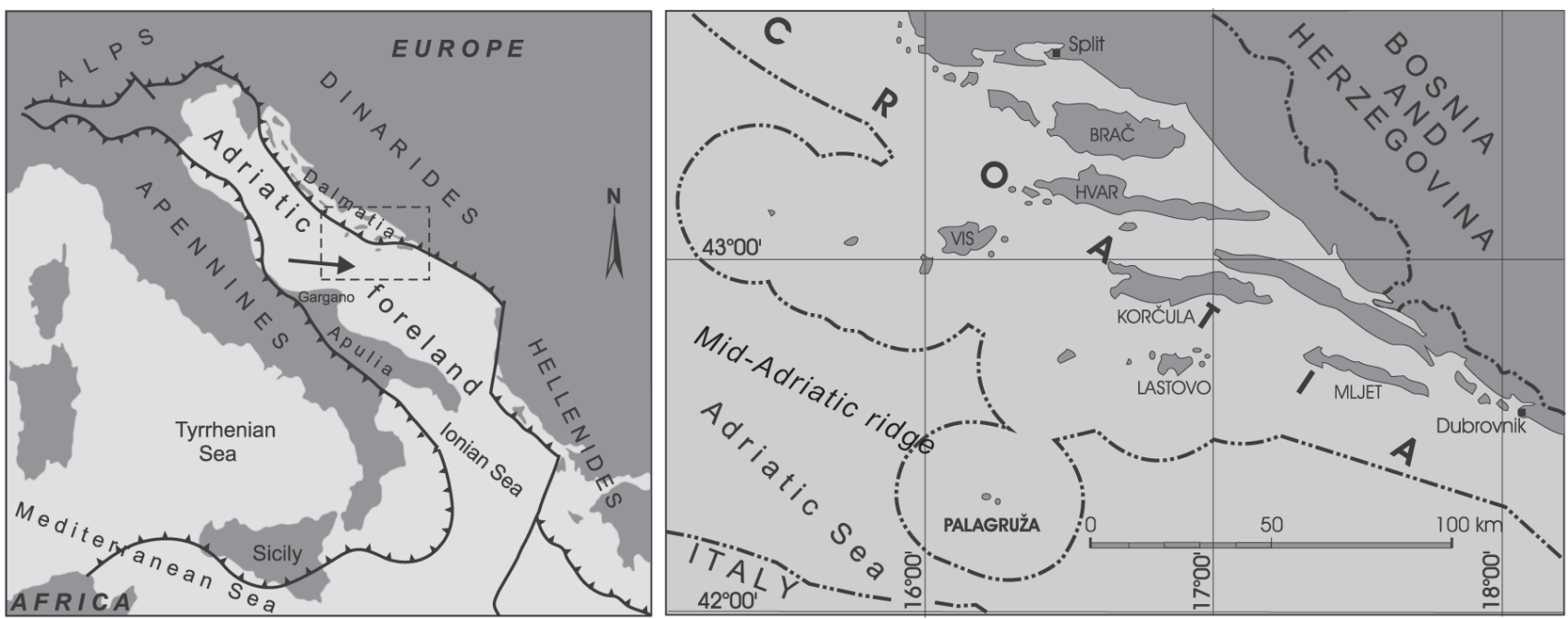

Figure 1: Simplified geotectonic map of the wider Adriatic region, and location of the Palagruža archipelago. 
mations of the central Adriatic Basin is covered by thick Neogene siliciclastic deposits (BERTOTTI et al., 2001). These formations are known from boreholes and seismic profiles (e.g., GRANDIĆ et al., 2002, and references therein), and Palagruža is the only place in the whole region where some of these units are exposed above sea level.

BOGNAR (1995) proposed that Palagruža represents a "pop-up" structure, which consists of a fault-bounded fragment of continental crust that is being pushed laterally and vertically by compressional tectonic forces. In other words, Palagruža is uplifting due to the head-on collision between the converging Apenninic and Dinaridic orogenic systems (Fig. 1), and, for this very reason, it is subject to seismic activity.

Through modelling GPS measurements of crustal velocity along a transverse profile across the southern Adriatic microplate and south-central Dinarides, BENNETT et al. (2008) assumed a NNE dipping thrust fault, which surfaces along the offshore of southern Dalmatia, between the islands of Vis and Palagruža, not far north of Palagruža. BENNETT et al. (2008) argued for SW-migrating deformation in an active fold-and-thrust belt as a consequence of uninterrupted subduction of the southern Adria mantle lithosphere beneath Eurasia since the Eocene. In this tectono-seismic scenario, Palagruža is located on the footwall of the thrust not far from its line of emergence to the north, and its present horizontal movement toward the NE in respect to fixed Eurasia is about $5 \mathrm{~mm} / \mathrm{yr}$ (BENNETT et al., 2008).

Recent regional seismic-stratigraphic data (GRANDIĆ et al., 2002) suggest that diapirism probably contributes to the current crustal uplifting along two WNW-ESE divergent reverse faults (suggesting transpression), which delimit the Palagruža submarine rise - Palagruža high (BERTOTTI et al., 2001) or Mid-Adriatic ridge (GRANDIĆ et al., 1997; GELETTI et al., 2008), in the southern and northern off shore of the island. GELETTI et al. (2008) argued for a Miocene onset of the diapirism, according to seismostratigraphic interpretations, whereas the related deformations continue to date.

At present, the central Adriatic is seismically active (e.g. HERAK et al., 1996; GRANDIĆ et al., 2002; CHIARABBA et al., 2005; RIDENTE \& TRINCARDI, 2006). The most important seismic event in recent times was represented by the 1988 swarm, which started in February 1988, and ended early in 1989. More than 100 quakes $>3 \mathrm{M}$ were recorded during this period, with epicenters spread over an area about $30 \mathrm{~km}$ long (in a NE-SW direction) and $20 \mathrm{~km}$ wide (HERAK et al., 1996). The largest earthquake of this sequence reached a magnitude of 5.3, and its epicenter was located $38 \mathrm{~km} \mathrm{SE}$ of Palagruža, with a focal mechanism indicating slightly oblique reverse faulting with an E-W strike (RIDENTE \& TRINCARDI, 2006). This is consistent with the general deformation on strike-slip and thrust faults resulting in NE-SW shortening along the eastern coast of the Adriatic Sea (BATTAGLIA et al., 2004).

In summary, the Mid-Adriatic ridge belongs to the Adriatic foreland, and its origin is related to combined strike-slip faulting and vertical salt movement. Palagruža is probably placed at the topmost part of an active diapiric structure characterized by a very deep root.

\section{SEDIMENTARY UNITS AND TECTONICS}

The sedimentary units exposed at Velika Palagruža are described according to direct observations of key outcrops and their distribution in our original geologic map (Fig. 2), which highlights the remarkably complex geology of this tiny island. However, it should be stressed that a more precise age determination, as well as more detailed stratigraphic and tectonic relationships between the sedimentary units, requires further research. Nevertheless, the units are described below and are organized according to their proposed stratigraphic position.

\section{1. Žalo unit}

An outcrop of stratified yellowish siltstones and green-grey claystone associated with gypsum is located in the southern central part of the island, about $50 \mathrm{~m}$ west of a fishermans shack at the western end of Žalo beach (Location 1, Fig. 2). These rocks comprise a stratigraphic succession from a basal homogeneous green-gray clay unit, to a lens of fractured white gypsum about $1.5 \mathrm{~m}$ thick, overlain by a finely stratified clay-rich siltstone unit containing disperse gypsum, and terminating with a second horizon of green-gray clay-rich siltstone (Fig. 3A). Fragments and whole shells of microgastropods, and small vertebrate bones were observed in a sample of green-gray clay/claystone from the Žalo outcrop, but have not so far yielded a taxonomic determination.

The succession is covered by a rockfall of dolomite boulders. Apart from the fractured gypsum, where greengray clay fills the fractures (Fig. 3B), this outcrop appears undeformed, with regular, parallel bedding constantly dipping $32^{\circ} \mathrm{NE}$.

The green-gray clay of the Žalo unit is also exposed in the lower part of a ravine at Picokare, about $200 \mathrm{~m}$ further west (Fig. 4A). Some metres above this outcrop, a package of thin-bedded, beige-yellowish dolomite layers are exposed, with a dip of $27^{\circ} \mathrm{NW}$. Unfortunately, the contact between the clay and this thin-layered unit is not exposed, but it seems that the Žalo unit occupies this part of the island, from the fisherman shack at Žalo beach to the Picokare gully, and it is covered by boulder rock fall and south-dipping coarse talus (see Figs. 2 and 4A). On the other hand, the contact between the Žalo unit clay and the Lanterna unit dolomite with chert (see section 3.2.) to the west of the Picokare ravine, is well exposed, and it is represented by a sharp discordance (Fig. 4A). Practically, the thick-bedded dolomite layers with chert of the Lanterna unit (unit A, see below), which dip steelpy to the SW, are cut by a flat and smooth undulatory surface, with a dip of about $45^{\circ}$ toward the E. The clay of the Žalo unit is found resting on top, against this surface (Fig. 4B). We are still uncertain on the exact nature of this discordance, which does not appear to be a simple angular unconformity. We do not exclude that the flat discordance surface is actu- 


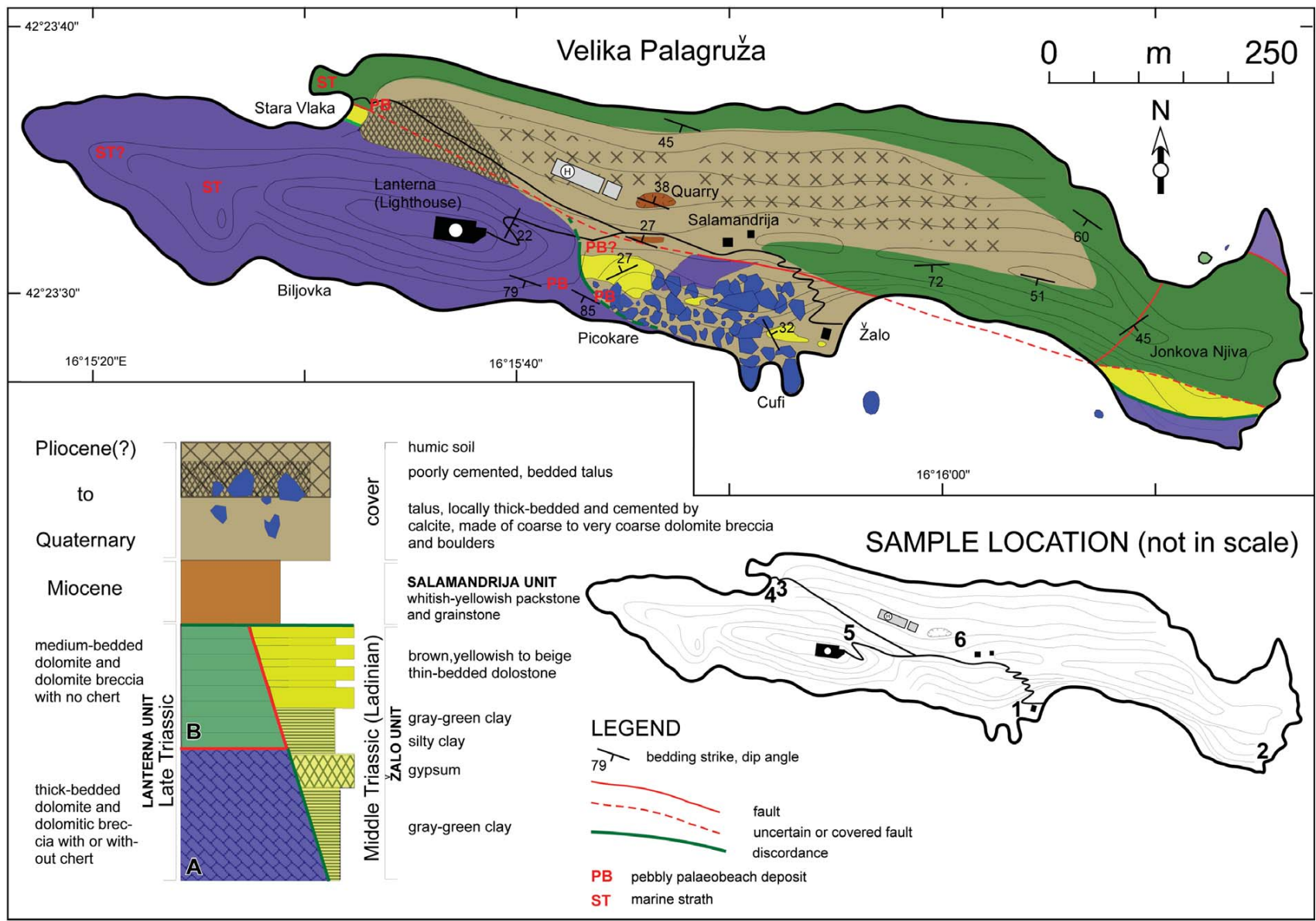

Figure 2: Geologic map and synthetic stratigraphic column of the island of Velika Palagruža. Sampling locations on inserted map (not in scale): 1 - samples Pal-5 and Pal-6; 2 - samples Pal-22 and Pal-23; 3 - sample Pal-14; 4 - sample Pal-16; 5 - sample Pal-12D; 6 - samples Pal-10 and Pal-13.

ally a deformed fault plane, as some oblique slickenside striations on the smooth surface suggest, and that the Žalo unit has been put in place against the already tilted Lanterna dolomites by the combined action of oblique-slip faulting and diapiric uplifting. However, the age relationship between the Žalo unit and the Lanterna unit is still uncertain (see below), which limits the plausibility of the interpretation for this rather odd structural situation.

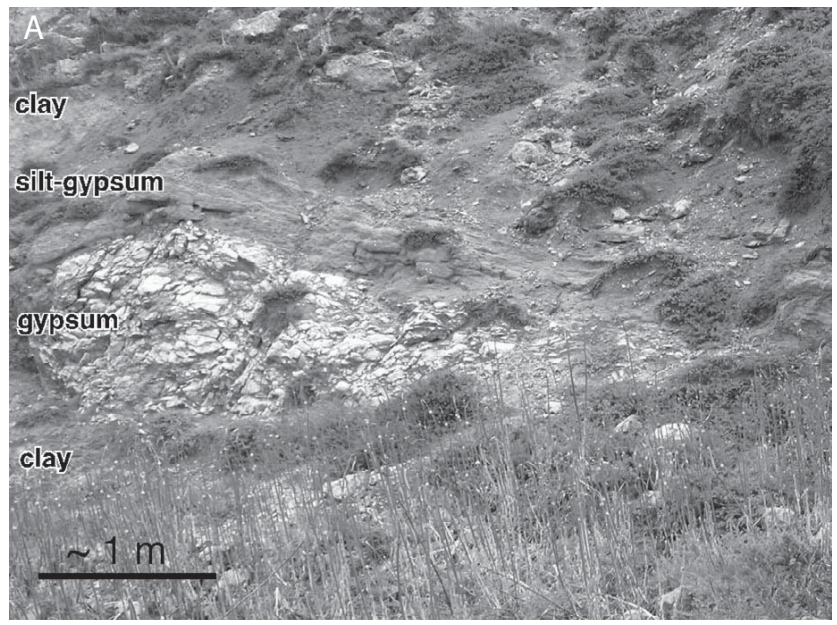

Another key exposure of the Žalo unit is located on the southeasternmost coast of the island, south of a locality called Jonkova Njiva (Fig. 5A). As at Picokare, the Žalo unit rests on top of thick-bedded dolomite layers of the lower part of the Lanterna unit (i.e., unit A in the legend of Fig. 2). The rocks, which include marly siltstones containing disperse nodules of gypsum, and a few layers of stromatolitic limestone, are strongly deformed (Fig. 5B). On the north side of

Figure 3: A) Outcrop of the siliciclastics and gypsum of the Žalo unit west of the Žalo beach; B) close up of the fractured gypsum with greenish-gray clay

filling in the cracks.

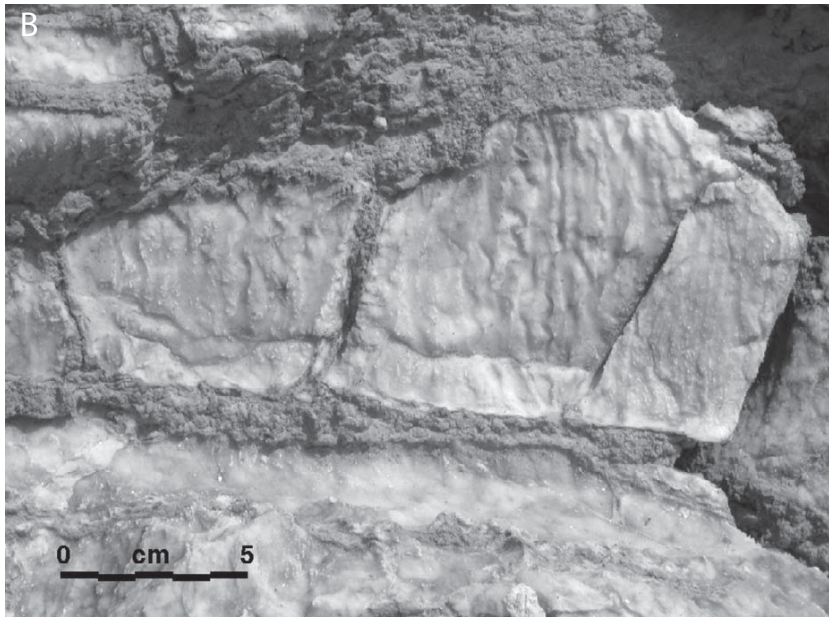



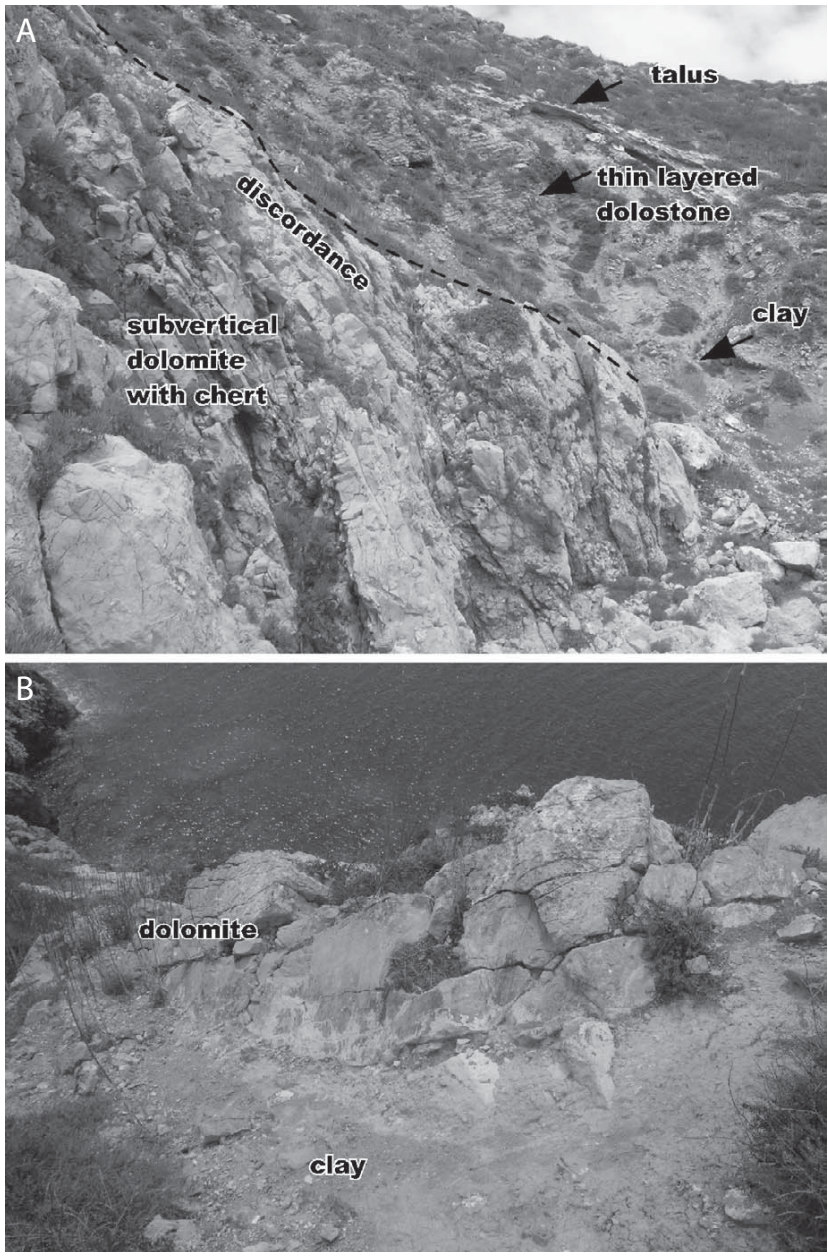

Figure 4: A) Panoramic view of the Picokare ravine from the south, showing discordance (?diapiric contact) between the Žalo unit clay and the subvertical, thick-bedded dolomites with chert of the Lanterna unit $\mathrm{A}$, both capped by stratified talus; B) Close up (from above) of the contact between extremely deformed greenish clay of the Žalo unit and the dolomite of the Lanterna unit A.

this outcrop a WNW-ESE striking subvertical oblique-slip fault puts the Žalo unit in contact with strongly deformed, medium-thick bedded dolomites and dolomite breccias of the presumed upper part of the Lanterna unit (unit B). This fault is probably the continuation of the oblique-slip fault that dissects the whole length of the island from Stara Vlaka on the NW, to the southeastern point of Jonkova Njiva, where Žalo unit rocks occur in a strongly deformed fault zone.

A similar situation is found on the south side of the Stara Vlaka cove (Figs. 2 and 6), where strongly deformed thinbedded dolomites and green-grey clay are found within the highly tectonized zone of the same oblique-slip fault (Fig. $6 \mathrm{~A}$ and $\mathrm{B})$.

\subsubsection{Palynostratigraphy of the Žalo unit}

To overcome the age uncertainty of the Žalo unit, and assess its palaeoenvironmental and biostratigraphic attributes, a detailed palynological study of a number of soft rock samples from various outcrops throughout the island, was undertaken.

Sample Pal-5 (Žalo unit gypsum, W of Žalo beach, location 1 on Fig. 2) is palynologically barren.
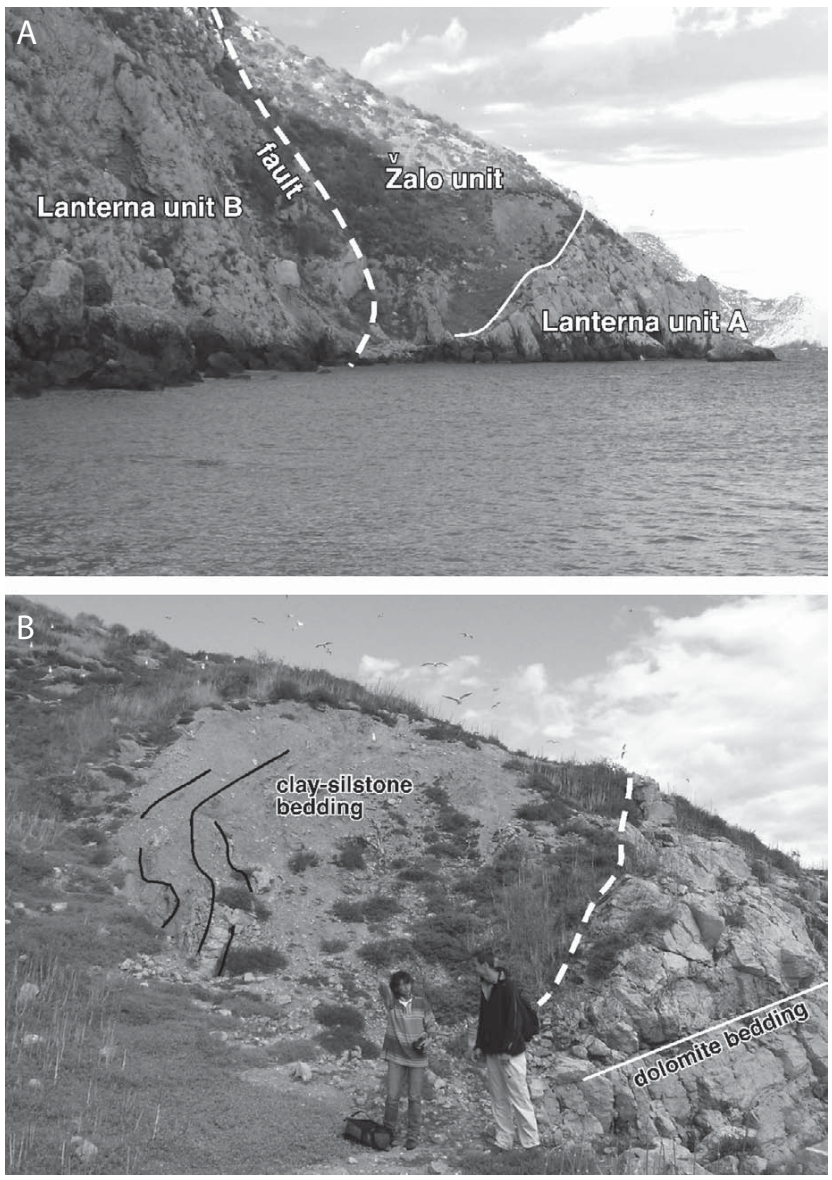

Figure 5: A) Panoramic view of the outcrop of the Žalo unit near Jonkova Njiva, and B) close up of the discordant (?diapiric) contact with the underlying Lanterna unit $\mathrm{A}$.

Sample Pal-6 (Žalo unit silty claystone, W of Žalo beach, location 1 on Fig. 2). Palynoflora of the sample Pal-6 (APPENDIX 1 and Fig. 7) is represented by a diverse and wellpreserved assemblage of predominantly sporomorphs and may well be correlated to the palynoflora of the European and Circum-Mediterranean independently dated Ladinian sections (VISSCHER \& BRUGMAN, 1981; WARRINGTON, 2002; SCHULZ \& HEUNISCH, 2005).

In the Alpine region of the Dolomites in Italy, the palynoflora of sample Pal-6 corresponds to the palynological secatus - dimorphus phase of VAN DER EEM (1983). This type of palynoflora has been described from sections of southeastern Switzerland (SCHEURING, 1978) and the Dolomites (BLENDINGER, 1988; HOCHULI \& ROGHI, 2002), as well as from Liechtenstein,western Austria (BRÜHWILER et al., 2007) and Hungary where it has been designated as meieri - scheuringii phase (GÓCZÁN \& ORAVECZ-SCHEFFER, 1993; KOVÁCS et al., 1994). The secatus - dimorphus phase concours with the ammonoid gredleri zone and archelaus zone (VAN DER EEM, 1983; BRUGMAN, 1986), which, according to BRACK et al. (2005), are Late Fassanian-Early Langobardian in age. Among the stratigraphically significant sporomorphs that are shared between the secatus - dimorphus phase and the palynoflora of sample Pal-6, Heliosaccus dimorphus has a range within the secatus - dimorphus phase whilst Camerosporites secatus, Duplicisporites gran- 

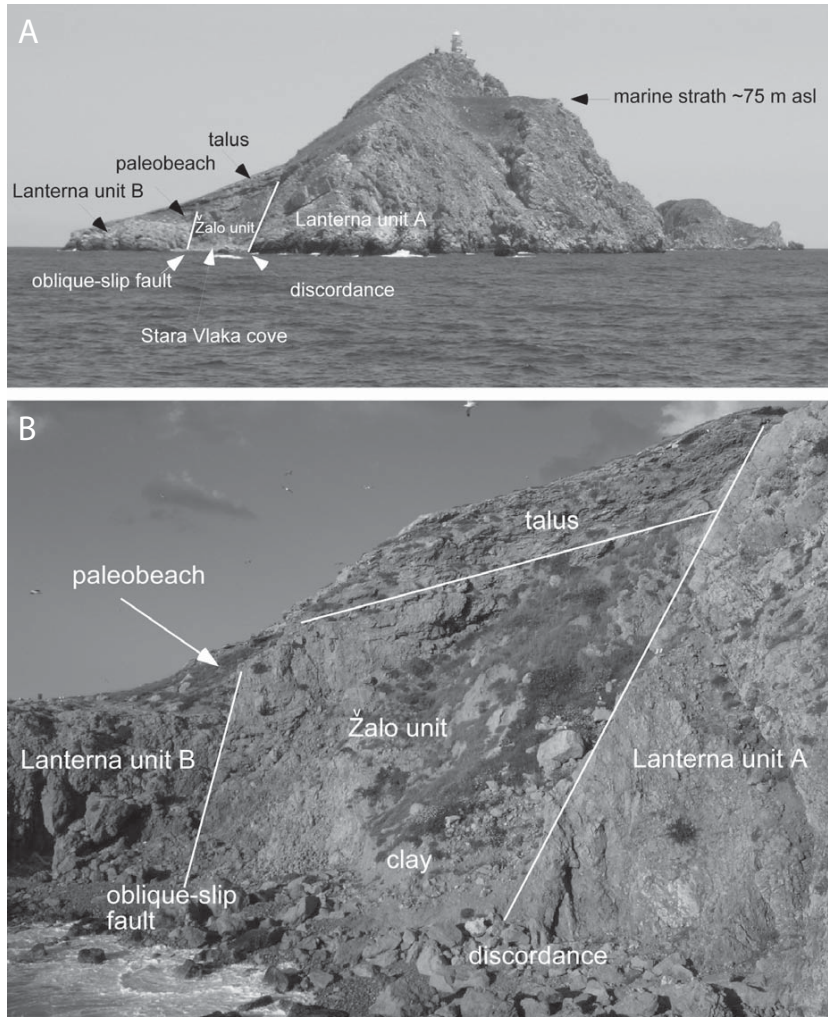

Figure 6: A) panoramic view of the western point of Velika Palagruža looking east with the indications of the geologic features described in the text; B) The exposure at Stara Vlaka cove showing the fault contact between a tectonized Žalo unit and the dolomite breccia of the Lanterna unit B, and the discordant contact with the thick-bedded dolomite of the Lanterna unit A. The dolomite breccia of Lanterna unit B is covered by a pebbly palaeobeach deposit resting below a talus slope.

ulatus, Sellaspora rugoverrucata, Kyrtomisporis ervei and Brachysaccus neomundanus first appear at the base of the early Fassanian ammonoid curionii zone (Earliest Ladinian), i.e. plurianulatus - secatus phase (VAN DER EEM, 1983; BRUGMAN, 1986). According to BRÜHWILER et al. (2007), the first appearance of $C$. secatus and D. granulatus is higher and corresponds to the base of secatus - dimorphus phase of the ammonoid gredleri zone. Last appearance of Cannanaropollis scheuringii is at the top of Late Langobardian (Latest Ladinian) secatus - vigens phase which correspond to the ammonoid regoledanus zone (VAN DER EEM, 1983; BRUGMAN, 1986). The last appearance of this taxon has been found at the top of the Ladinian also in other parts of the Alpine facies (SCHEURING, 1978; GÓCZÁN \& ORAVECZ-SCHEFFER, 1993; KOVÁCS et al., 1994). Several taxa of the Pal-6 palynoflora also occur in other Alpine sections, e.g. Haberkornia parva/gudati and Podosporites amicus, ranging approximately with the secatus - dimorphus phase, and Doubingerispora filamentosa, which first appears at the base of the Ladinian. Sample Pal-6 also contains the stratigraphically significant sporomorphs Staurosaccites quadrifidus, Ovalipollis pseudoalatus and Partitisporites spp., which first appear at the base of the plurianulatus - novimundanus phase of the ammonoid Nevadites sp. (=secedensis) zone, previously considered as early Fassanian (earliest Ladinian) by VAN DER EEM (1983) and BRUGMAN (1986).
After the acceptance of the GSSP for the base of the Ladinian stage at the base of the ammonoid curionii zone (BRACK et al., 2005), the plurianulatus - novimundanus phase represents the latest Anisian palynofloral development. The plurianulatus-novimundanus phase contains, in the lower part, the Late Anisian sporomorphs Stellapollenites thiergartii and Dyupetalum vicentinense, and its top is defined by the last appearance of Illinites chitonoides and Concentricisporites plurianulatus (BRUGMAN, 1986). Since these sporomorphs have not been identified in the sample Pal-6, the presence of S. quadrifidus, O. pseudoalatus and Partitisporites spp. alone suggests an age not older then earliest Ladinian. Considering the highest range of the sample Pal-6 palynoflora, the lack of Enzonalasporites vigens, Weylandites magmus, and "Lueckisporites" cf. singhii, which first appear at the base of secatus - vigens phase of the ammonoid regoledanus zone, treated as Late Langobardian (Latest Ladinian) (VAN DER EEM, 1983, BRUGMAN, 1986; BROGLIO LORIGA et al., 1999), suggests an age not younger than Latest Ladinian.

In the Germanic facies, the palynoflora of sample Pal-6 corresponds to the palynological record of the Lettenkohle successions (Lower Keuper). In Poland, ORŁOWSKA-ZWOLIŃSKA (1983) designated the Lettenkohle palynoflora as representing the Heliosaccus dimorphus Zone. In Germany, several palynological zones, phases and subphases have been described, which allowed correlation to the Alpine time equivalents (REITZ, 1985; HEUNISCH, 1986; VAN DEN BERGH, 1987; BRUGMAN et al., 1988; VAN BERGEN \& KERP, 1990; BRUGMAN et al., 1994; BEUTLER et al., 1996; HEUNISCH, 1999). The palynoflora of the Lettenkohle successions in France correspond to the correlatives in other parts of the Germanic facies (ADLOFF et al., 1984; COURTINAT \& RIO, 2004).

The palynoflora of the Lettenkeuper has been dated based on both independent control and palynological correlation with the Alpine record. The palynofloral record from southern Germany, which is enhanced within the iliacoides - dimorphus sub/phase (VAN DEN BERGH, 1987; BRUGMAN et al., 1988) and perforatus - dimorphus phase of (VAN BERGEN \& KERP, 1990; BRUGMAN et al. (1994), corresponds to the Alpine secatus - dimorphus phase.

In the Circum-Mediterranean region of Spain, the palynoflora of sample Pal-6 corresponds to the secatus - meieri subphase of BESEMS (1983) which represents the lower part of the Camerosporites secatus phase (VISSCHER \& KRYSTYN 1978; VISSCHER \& VAN DER ZWAN, 1981; VAN DER EEM, 1983) and is similar to the palynoflora of Lettenkohle as described by GARCIA GIL \& DIEZ (2006). In Libya, ADLOFF et al. (1986) reported on a palynoflora, which they correlate, to the Alpine secatus - dimorphus phase of VAN DER EEM (1983). In Israel, ESHET (1990) described the palynoflora from the ammonoid controlled section which has been assigned to the Podosporites amicus Zone corresponding in many elements to the European correlatives. Syrian subsurface sections revealed a palynoflora which YAROSHENKO \& BASH IMAM (1995) and LUČIĆ et al. (2003) compare to the palynofloras of the Circum-Mediterranean and European Ladinian correlatives. 


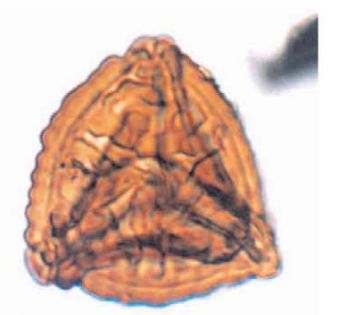

1

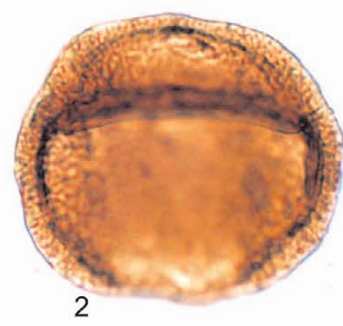

$20 \mu \mathrm{m}$
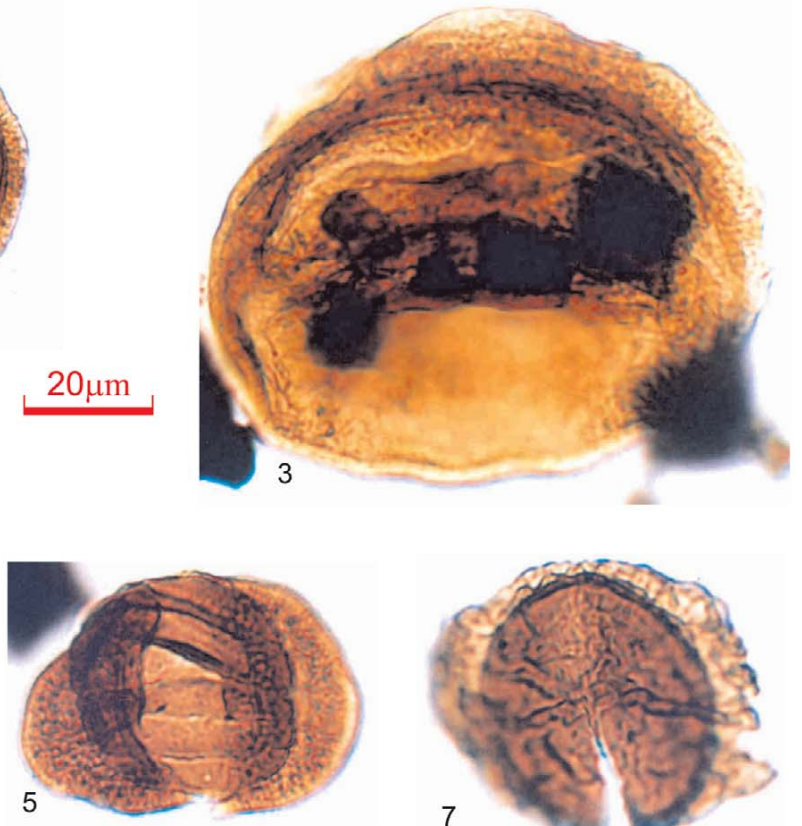

4
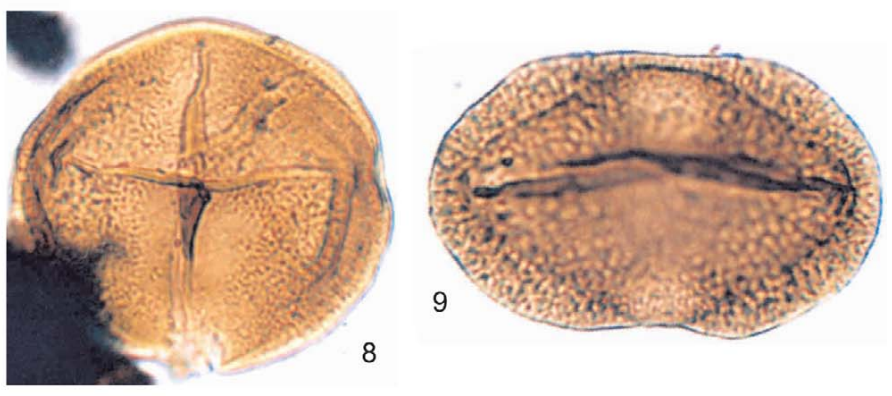

6
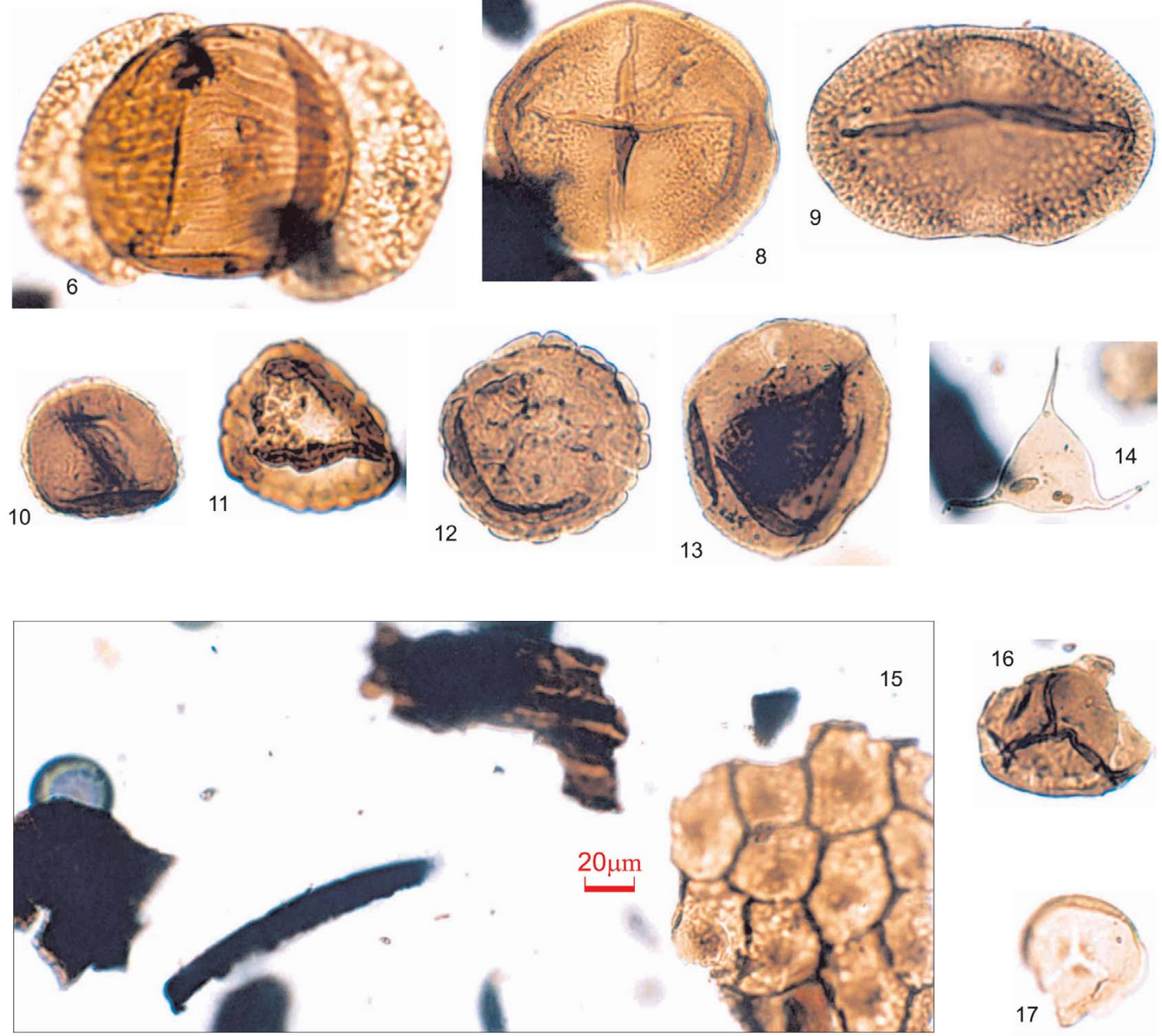

Figure 7: Palynomorphs and palynofacies of the Žalo unit claystone sample Pal-6 (location 1 on Fig. 2). Autochthonous Ladinian: 1) Kyrtomisporis ervei, 2) Doubingerispora filamentosa, 3) Cannanoropollis scheuringii, 4) Heliosaccus dimorphus, 5) Lunatisporites acutus, 6) Striatoabieites balmei, 7) Triadispora plicata, 8) Ovalipollis pseudoalatus, 9) Staurosaccites quadrifidus, 10) Haberkornia parva, 11) Duplicisporites verrucosus, 12) Camerosporites secatus, 13) Aulisporites astigmosus, and 14) Veryhachium sp., 15) Palynofacies. Reworked Lower Triassic: 16) Densoisporites nejburgii and 17) Endosporites papillatus. 
Along with the authochtonous Ladinian palynoflora, sample Pal-6 also contains reworked sporomorphs (APPENDIX 2, Fig. 7/16, 17), among which, Endosporites papillatus and Densoisporites nejburgii suggest reworking from Lower Triassic successions. Several sporomorphs assigned as cf. Lueckisporites virrkiae, Limitisporites sp. and cf. Nuskoisporites sp. indicate reworking most likely from Permian successions.

From the palynological point of view, the palynoflora of sample Pal-6 is almost identical to the palynoflora from the surface sections of the diapiric structure at Komiža, the island of Vis (BELAK et al., 2005), which has been designated as the dimorphus Interval Zone and interpreted as Late Fassanian-Early Langobardian in age. At the Komiža site, BELAK et al. (2005) also reported discovery of the dasycladal alga Diplopora nodosa with a Late Anisian-Ladinian range according to GRGASOVIĆ \& SOKAČ (2003) as well as the problematic taxon Plexoramea cerebriformis with a Middle Anisian-Carnian range according to GORIČAN et al. (2005). At present, the findings of $D$. nodosa represent the stratigraphycally narrowest independent control of the described palynoflora in the area under consideration.

Sample Pal-14 (Žalo unit clay, Stara Vlaka cove, location 3 on Fig. 2) contains a moderately to poorly preserved palynoflora, predominantly of sporomorphs, generally similar to the palynoflora of sample Pal-6, and may therefore be considered Ladinian in age.

Sample Pal-22 (Žalo unit stromatolitic limestone, SE of Jonkova Njiva, location 2 on Fig. 2) contains a small amount of degraded palynological organic matter and only a few poorly preserved bisaccate pollen grains and cf. Camerosporites secatus suggesting a Ladinian-Carnian age.

Sample Pal-23 (Žalo unit marly siltstones, SE of Jonkova Njiva, location 2 on Fig. 2) contains palynoflora similar to Pal-14. However, the assemblage is less diverse allowing an age assignment within a wider Ladinian-Carnian range.

\subsubsection{Age of the Žalo unit}

According to the palynostratigraphy reported here (section 3.1.1., APPENDIX 1, Fig. 7/1-15), the Žalo unit was dated as Middle Triassic in age (Ladinian).

The Žalo unit was dated as Lower Triassic by SOKAČ et al. (1980), according to the Lower Triassic foraminifera Meandrospira pusilla found in limestone microlithoclasts of quartzose calcarenitic sandstones. Unfortunately, neither the sandstones mentioned by Sokač and co-workers, nor the microfossils were found within analysed outcrops or elsewhere in the Žalo unit. However, redeposited Lower Triassic palynomorphs were found (see chapter 3.1.1., APPENDIX 2, Fig. $7 / 16,17)$. Thus, it is suggested that SOKAČ et al. (1980) reported on presumably Ladinian sandstones containing redeposited Lower Triassic limestone microlithoclasts.

\subsubsection{Palynofacies of the Žalo unit}

The composition of the palynological organic matter of samples Pal-6, Pal-14 and Pal-23 is almost identical. Sample Pal-6 (Fig. 7/15) is characterized by a better preservation state of the organic matter in respect to other samples. Most of the organic matter consists of fragments of woody tissue $(90 \%)$ followed by leaf (cuticle) remains (5\%), and palynomorphs (5\%). Opaque clasts of presumably woody tissue (as suggested by the shape of the clasts) are rare $(<1 \%)$. Amorphous organic matter and structureless organic matter occur in traces showing thier liptinitic origin under blue light. Woody tissue is represented by brown to dark-brown, partly well structured, variably sized (mostly 5-50 $\mu$ m, partly up to 400 $\mu \mathrm{m})$ and shaped (equidimensional to lath-shaped) particles that are predominantly angular and weakly sorted. Cuticle remains mostly occur as well preserved, structured fragments $(50-500 \mu \mathrm{m})$. Most of the palynomorphs are well preserved and represented predominantly by terrestrial palynomorphs, i.e. sporomorphs $(94 \%)$ of which bisaccate pollen $(64 \%)$ is most abundant, followed by Circumpolles (20\%), spores $(10 \%)$, monosaccate pollen (3\%), and asaccate pollen $(3 \%)$. Aquatic palynomorphs (6\%) are mostly represented by prasinophyceans (60\%) followed by acritarchs (34\%), and chlorophyceans $(6 \%)$. Pyrite inclusions have not been observed. Samples Pal-14 and Pal-23 differ from Pal-6 in a somewhat lower abundance of cuticle fragments as well as their lower abundance and diversity of sporomorph assemblages.

The palynological composition of the sedimentary organic matter of the analyzed samples indicate that this silty claystone was deposited in a low-energy, dysoxic environment, proximal to the input of terrestrial organic matter and under fluvial and open marine influence, and may, therefore, be characterized as marine-brackish-fluvial tidal flat (cf. TYSON, 1995 and BATTEN, 2002). The environmental interpretation of sample Pal-6 can be also applied to that for samples Pal-14 and Pal-23 since their palynofacies features are almost identical.

Sample Pal-22 contains a small amount of palynological organic matter mostly consisting of amorphous organic matter $(95 \%)$, part of which is represented by clasts of fragmented cyanobacterial laminae. Woody tissue $(5 \%)$ is weakly structured. Sporomorphs occur in very low frequency. Except for a few Leiosphaeridia, other aquatic palynomorphs have not been observed.

The palynofacies features of sample Pal-22 suggest a carbonate, shallow water depositional setting with scarce terrestrial input.

\subsubsection{Palaeoclimatological and palaeoenvironmental intepretation of the Žalo unit}

For the purposes of palaeoclimatological/palaeoenvironmental interpretation, the palynomorphs are grouped into categories indicating their botanical affinity and ecological sensitivity (APPENDIX 3) according to VISSCHER \& VAN DER ZWAN (1981), BRUGMAN et al. (1994), VISSCHER et al. (1994) and ROGHI (2004).

Groups A-G are of equisetophytic, lycopodiaphytic and pterophytic and category $\mathrm{H}$ of bennettitalean and gnetalean affinity. Groups A-H reflect hygrophytic plant communities of swamps, marshes, mangrovas and generally wet and water-saturated substrates of fluviatile and lacustrine environ- 
ments. Group I is of bryophytic and group $\mathrm{J}$ is of pteridosperm origin while groups $\mathrm{K}-\mathrm{P}$ are of coniferalen affinity, respectively. Groups I-P reflect xerophytic plant communities of hinterland vegetation. Group P represents prasynophycean algae and group Q coenobial chlorophycean algae which reflect freshwater-brackish to intertidal shallow marine and lagoonal depositional sets. Group Q represents phytoplankton of marine environments.

The quantitative distribution of the groups within the palynoflora of Pal-6 (APPENDIXES 1 and 3) shows that the groups K-P constitute $80 \%$ of the whole palynological assemblage indicating predominantly xerophytic plant communities which suggests semi-arid climate conditions. This may well be supported by high frequencies of group L (Ovalipollis/Staurosaccites; $26.6 \%$ ) and group $\mathrm{P}$ (Circumpolles; 19.8\%), which are indicators of regional aridity, and a high frequency of bisaccate pollen $(64 \%)$ indicating the proximity of xerophytic plant communities of the hinterland vegetation.

\subsubsection{Sulphur isotopes of the Žalo unit gypsum}

To separately test the Triassic age for the Žalo unit, we analyzed the sulfur isotope composition $\left(\delta^{34} \mathrm{~S}\right)$ of selenitic gypsum from the outcrop Pal-5, (location 1, Fig. 2). Sulfur isotope measurements were made both on original evaporite minerals and on samples that were leached in water and reprecipitated as barium sulfate prior to isotope analysis. Both replicates are presented in Table 1 . The isotope analyses are in parts per thousand or \%o and the standard is the Canon Diablo Troilite (CDT). The analytical error of the isotope measurement is $\pm 0.2 \%$.

In theory, the $\delta^{34} \mathrm{~S}$ of marine gypsum or other sulfateevaporite mineral should be related to the $\delta^{34} \mathrm{~S}$ of global marine sulfate at the time the evaporite formed (ŠIFTAR, 1987). The $\delta^{34} \mathrm{~S}$ of global ocean sulfate was distinct in the Miocene ( $22 \%$ ) from the Permian to Triassic ( 10 to $15 \%$ ). Using the $\delta^{34} \mathrm{~S}$ of an evaporite mineral as a geochronological indicator can however be problematic. First, there can be isotope dynamics associated with evaporating basins; sulfur isotopes can be fractionated during precipitation and progressive evaporation and this will impact on the $\delta^{34} \mathrm{~S}$ of the sulfate in the evaporitic brine. Second, and more problematically, the sulfate that is used to form the evaporite mineral could come not from ocean-sulfate but from oxidized hydrogen sulfide $\left(\mathrm{H}_{2} \mathrm{~S}\right) . \mathrm{H}_{2} \mathrm{~S}$ forms from bacterial sulfate reduction in anoxic sediments and rocks; because of sulfur isotope fractionation during bacterial sulfate reduction, the $\mathrm{H}_{2} \mathrm{~S}$ formed has a $\delta^{34} \mathrm{~S}$ that is 10 to $50 \%$ o lower than the original sulfate. If this $\mathrm{H}_{2} \mathrm{~S}$ migrates and then oxidizes, the sulfate formed during oxidation will also be isotopically "light" and distinct from sea-

Table 1: $\delta^{34} \mathrm{~S}$ isotope data from samples of Palagruža Žalo unit gypsum (location 1 on Fig. 2; Fig. 3)

$\begin{array}{ccc}\text { Sample ID } & \mathrm{d}^{34} \text { S VCDT } & \text { Elemental Composition } \\ \text { GYP-A } & -11.4 & 16.1 \\ \text { GYP-C } & -11.5 & 12.7 \\ \text { GYP-D } & -11.1 & 12.0\end{array}$

water sulfate. For example, the microcrystalline gypsum slush mass found in the Frasassi caves (Italy) has $\delta^{34} \mathrm{~S}$ of $-13.7 \%$, and was likely formed from subaerial reaction between $\mathrm{H}_{2} \mathrm{~S}$ and a lower Jurassic limestone of the Calcare Massiccio Formation (e.g. MARIANI et al., 2007, and references therein). In this case, the $\mathrm{H}_{2} \mathrm{~S}$ originates from reductive dissolution of a Triassic anhydrite in the underlying Triassic Burano Formation.

The sample from Palagruža (GYP) has a similar $\delta^{34} \mathrm{~S}$ of $-11.4 \%$, which suggests that the source of the sulfate for this gypsum is not seawater, but instead reoxidized $\mathrm{H}_{2} \mathrm{~S}$. If the Palagruža gypsum were precipitated directly from Miocene, Triassic or Permian seawater then we would expect values similar to those typical for marine evaporites. Therefore, we cannot use the $\delta^{34} \mathrm{~S}$ of the Palagruža gypsum to place this unit in the chronological context.

\subsection{Lanterna unit}

The most widespread rocks found at Palagruža are grey, hard, cryptocrystalline dolomites, all of which make up the Lanterna unit. Except for the area covered by humic soil, rock fall, and talus on the northern side of the island and at Picokare, this unit is well exposed on the coastal cliffs all along the perimeter of the island (Fig. 2), and it includes medium- to thick-bedded dolomite and irregular bodies of massive dolomite breccia. However, in many places the rocks are strongly deformed, fractured, and tectonically brecciated to the point that it is often difficult to discern primary bedding. Moreover, dolomitization has also obliterated internal structures and fossils of the source limestone, which prevents palaeontological age and palaeoenvironmental determinations. Nevertheless, we have distinguished two subunits in the whole dolomite body of the island (unit A and unit B; see legend in Fig. 2) on the basis of bedding thickness and style, and the presence of nodular chert. However, the stratigraphic relationship between these two subunits is uncertain as they are separated by the oblique-slip fault, which cuts across the whole length of island from WNW to ESE.

The Lanterna unit A makes up the southwestern, most elevated part of the island, and both the northeastern and southeastern points of the Jonkova Njiva promontory. This unit would correspond to "the basal dolomite" described by BOŽIČEVIĆ et al. (1965). In the southern cliffs below the lighthouse between Picokare and Biljovka, beds dip steeply (subvertically) to the southwest (Fig. 2). Elsewhere in the northern sector of the island, bedding is not clear due to strong tectonization and the presence of massive bodies of coarse dolomite breccia. Its most distinguishing feature is medium- to thick-bedded cryptocrystalline dolomite containing nodules and lenses of gray chert aligned along bedding (Fig. 8). Thin-bedded dolomites interbedded with softer silty dolomite occure in the lowermost part of the unit (Fig. 9).

Gray to beige, medium to thin-bedded dolomite devoid of chert nodules is the distinguishing feature of the Lanterna unit $\mathrm{B}$, which makes up most of the central-northern part of the island (Fig. 2). The unit B is often strongly tectonized, and contains massive bodies of coarse dolomite breccia (Fig. 6B). 


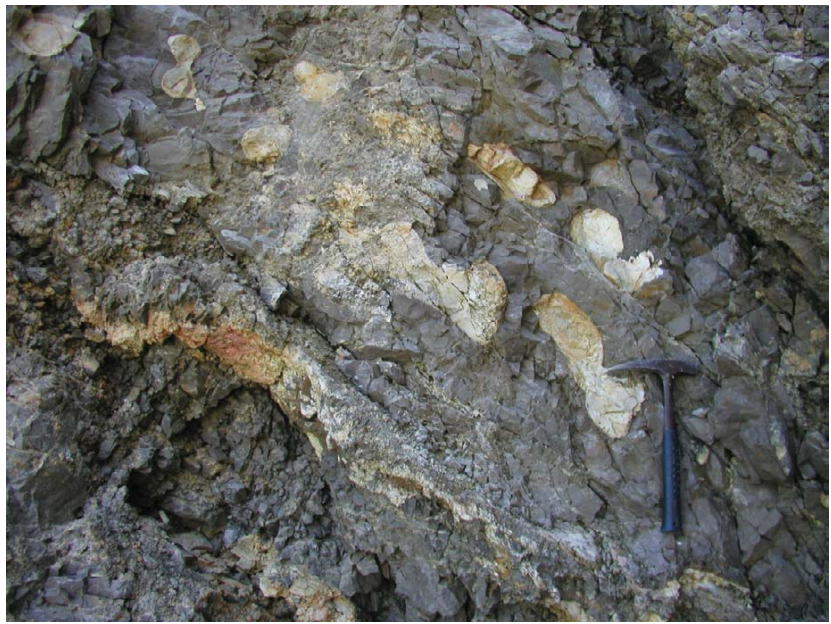

Figure 8: Chert nodules and layers of gray chert aligned along bedding of the Lanterna unit A dolomite (Stara Vlaka cove).

\subsubsection{Palynology of Lanterna unit A}

We analyzed a soft interbed of yellowish silty dolomite of the Lanterna unit A exposed at the first switchback on the trail to the lighthouse (Sample Pal-12D; location 5 on Fig. 2; Fig. 9), and in the coastal outcrop SW of Stara Vlaka (Sample Pal-16; location 4 on Fig. 2). Sample Pal-12D is palynologically barren whereas Sample Pal- 16 revealed a poorly preserved, undiversified sporomorph assemblage containing cf. Patinasporites densus, which first appears close to the base of the Carnian, i.e. at the base of the ammonoid aon zone palynologically characterized as the vigens - densus phase by VAN DER EEM (1983), and at the base of the ammonoid canadensis zone designated as Assemblage B by BROGLIO LORIGA et al. (1999), respectively. Occurrences of weakly preserved cf. Camerosporites secatus may suggest that sample Pal-16 is likely to be Carnian in age since its last appearance is placed at the top of Carnian (VISSCHER \& BRUGMAN, 1981; WARRINGTON, 2002).

Sample Pal-16 contains a small amount of organic matter, insufficient for palynofacies analysis or palaeoclimatological/palaeoenvironmental interpretation.

\subsubsection{Age and paleoenvironment of the Lanterna unit A}

The age of the Lanterna unit A is poorly defined as Late Triassic, according to palynological results (see section 3.2.1.).

Radiolarians reported by KOROLIJA et al. (1977) from the chert nodules of Lanterna unit A, and traces of Lithothamnion reported by BOŽIČEVIĆ et al. (1965), would indicate an age not older than Middle Jurassic for this formation. Unfortunately, neither microfossils nor macrofossils could be determined in the numerous samples of dolomite inspected in the field, or studied in thin sections. It is likely that dolomitization of the parent limestone, which led to a cryptocrystalline textural homogenization of these rocks, would have obliterated any original internal structure or microfossil trace.

The study of thin sections from the Lanterna unit chert nodules (Picokare and Stara Vlaka, Fig. 8) did not reveal any

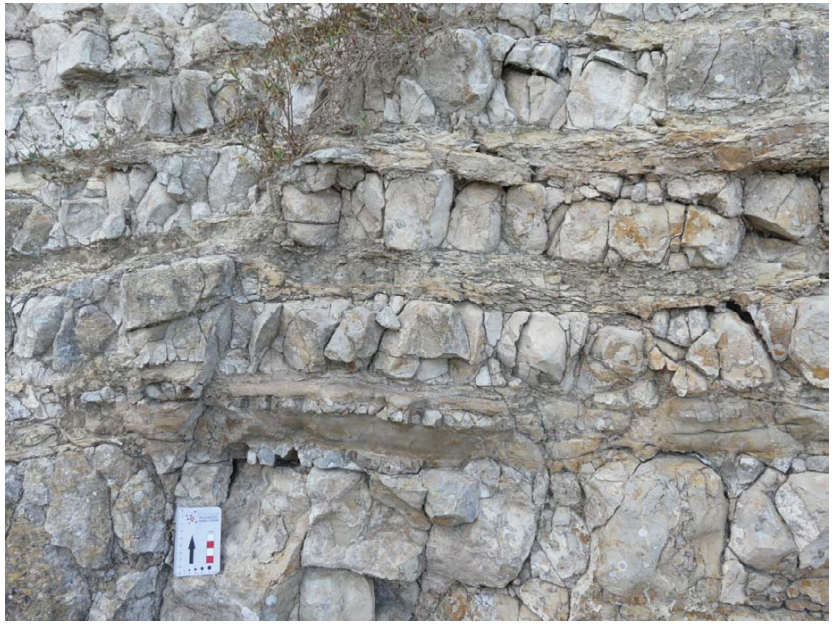

Figure 9: Outcrop of Upper Triassic thin-bedded dolomite interbedded with softer silty dolomite - Lanterna unit A (location 5 on Fig. 2). Scale bar in $\mathrm{cm}$.

radiolaria or any other kind of microfossil, nor lithic grains, which could have aided age assessment and determination of a palaeoenvironment setting for these rocks. However, the poorly preserved palynoflora of Pal-16 including Patinasporites, Enzonalasporites, Camerosporites and bisaccate pollen, suggests a semi-arid climate since these taxa represent coniferalean, xerophytic plant communities.

It should be noted that chert is common in the Late Triassic transitional and basinal limestone and dolomite successions of the southwestern Apennines (i.e. the Lagonegro-Molise basin; BERTINELLI et al., 2005; SERVIZIO GEOLOGICO D'ITALIA, 2007). These carbonate rocks also include breccia, shale, marl and siltstone units, but dolomitization seems to be restricted to the upper Triassic Calcari con Selce Formation, which represents proximal to transitional depositional environments. Dolomitization is not present in the Calcari con Selce in distal, deep-water successions. Thus, based on palynostratigraphy (section 3.2.1.) and the analogy with the central and southern Apenninic formations, we presume that the lower part of the Lanterna unit may represent proximal or transitional carbonate platform-to-basin deposits of Late Triassic age.

\subsection{Salamandrija unit}

The central part of Velika Palagruža (Salamandrija) is characterized by a regular, flat area, which dips toward the NNE, and is mostly covered by humic soil. A small quarry pit located some $50 \mathrm{~m}$ NE of the archaeological site of Salamandrija (KIRIGIN \& ČAČE, 1998; FORENBAHER \& KAISER, 2005; Fig. 2) reveals that this point of the island is composed of thick layers of light-grey to yellowish, porous bio-intra-lithoclastic to skeletal packstones and grainstones (biocalcarenites). Another outcrop occurs on the trail to the lighthouse, along the WNW-ESE striking fault (Fig. 2), separating the unit from the underlying rocks. Therefore, it is not possible to determine the exact stratigraphic relationship of this unit with the underlying rock units without new detailed field investigations. Nevertheless, the bedding attitude of the Salamandija unit exposed in the quarry pit is appro- 
ximately perpendicular in respect to the Lanterna unit B exposed along the crest of the island, suggesting a sharp angular unconformity.

\subsubsection{Biostratigraphy and depositional environment of the Salamandrija unit}

Study of thin sections of the Salamandrija biocalcarenite (samples Pal-10 and Pal-13, location 6 on Fig. 2) confirmed the presence of some microfossils reported by BOŽIČEVIĆ et al. (1965). Within recrystallized bioclastic-skeletal-lithoclastic grainstones (Fig. 10) biogenic debris mostly made up of bioclasts of sea urchins, red algae, mollusc shells and tests of benthic foraminifera was discovered. Among the latter, the most abundant are Elphidium sp. (including Elphidium crispum), followed by Asterigerinata sp., Melonis sp., Heterolepa sp., Gyroidinoides sp., Ammonia sp., Neoeponides sp., etc). E. crispum occurs, in the Mediterranean region, in Miocene sediments (AGIP, 1982).

In a preliminary study of the fossil content of the Salamandrija unit, BOŽIČEVIĆ et al. (1965) reported, besides casts and fragments of molluscs, fragments of calcareous algae, and recrystallized globigerinids, a number of benthic foraminifera including Robulus sp., Amphistegina sp., Nonion granosum, N. soldanii, Rotalia beccarii, Elphidium cripum and ostracod species Cythereis tricostata. According to BOŽIČEVIĆ et al. (1965), this fossil assemblage indicates a general Neogene age, similar to a marine Pliocene assemblage found in southern Apulia. However, the abundance of Elphidium sp. is suggestive of a Miocene age, and, in any case, as a detrital limestone made up of reworked bio- and lithoclasts, the fossil assemblage of the Salamandrija unit is not conducive to precise age determination.

The foraminiferal association indicates an inner shelf environment (cf. BOLTOVSKOY \& WRIGHT, 1976). BOŽIČEVIĆ et al. (1965) suggest a coastal sedimentary environ- ment based on the abundance of Amphistegina sp. Undefined subangular lithoclasts of older rocks are also present, including micritic limestones containing calpionellids (tintinnids). These redeposited subangular lithoclasts suggest that older rocks (including Mesozoic deeper-water micritic limestones) were deformed and exposed during sedimentation of the Salamandrija unit.

\subsubsection{Strontium isotopes of the Salamandrija unit}

As an independent method to determinate age for the Salamandrija unit, the ${ }^{87} \mathrm{Sr} /{ }^{86} \mathrm{Sr}$ composition of a bulk biocalcarenite sample from the Salamandrija quarry pit were analysed. (location 6 on Fig. 2), along with the shells of two modern intertidal gastropods, Natica millepunctata and $\mathrm{Pa}$ tella coerulea, collected at the island of Hvar and representing the present strontium isotopic composition of Adriatic seawater. In addition, a sample of pelagosite, which represents a bioaragonite related to the cyanobacterial activity in the supratidal zone (see section 4.3.), and a sample of dolomite from the Lanterna unit A were also analysed. Analysis was undertaken at the Berkeley Institute for Isotope Geochemistry, using sample preparation and an analytical procedure similar to that described by DePAOLO \& INGRAM (1985).

The results are shown in Table 2, and plotted in Fig. 11 against the curve of seawater strontium composition from the Permian to Recent (McARTHUR et al., 2001). The composition of the Lanterna unit A dolomite resulted in an ambiguous age determination, because of strong diagenetic alteration of the parent rock. The ${ }^{87} \mathrm{Sr} /{ }^{86} \mathrm{Sr}$ value of 0.709072 from the Salamandrija biocalcarenites provides a minimum age of about 9 Ma (i.e. lower Tortonian).

\subsubsection{Age of the Salamandrija unit}

Salamandrija biocalcarenites contain a wealth of microfossils and skeletal fragments of shallow-marine benthic fora-

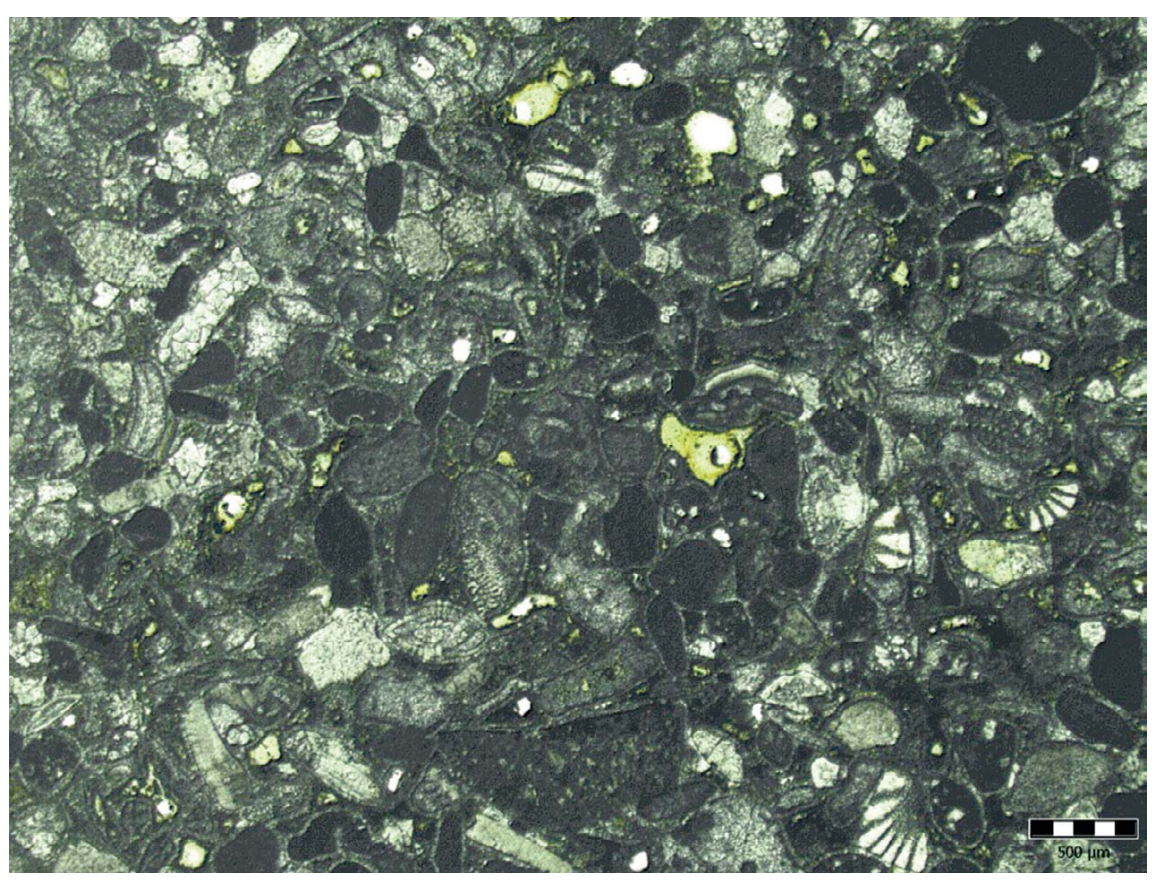

Figure 10: Microfacies and microfossils in the Miocene biocalcarenite of the Salamandrija unit (sample Pal-13, location 6 on Fig. 2). Scale bar $0.5 \mathrm{~mm}$. 
TABLE 2: Strontium isotope ratios of the Palagruža (PLG) samples: Lanterna unit A dolomite (cliff near Picokare, Fig. 2), Salamandrija unit biocalcarenite (locality 6 on Fig. 2) and Pelagosite sample (cliff near Picokare, Fig. 2) compared with modern mollusc shells from the Adriatic Sea (island of Hvar - HVA)

$\begin{array}{ccccc}\text { Sample } & \text { Material } & \text { Formation } & \text { Age } & \text { Error } \pm \\ \text { PLG/05-4 D } & \text { dolomite } & \text { Lanterna unit A } & \text { Late Triassic (?) } & 0.707490 \\ \text { PLG/05-10 L } & \text { limestone } & \text { Salamandrija unit } & \text { Late Miocene } & 0.000008 \\ \text { PLG/05-4 P } & \text { aragonite } & \text { Pelagosite } & \text { Holocene } & 0.709072 \\ \text { HVA/07 NAT } & \text { calcite } & \text { Natica shell } & \text { Present } & 0.709232 \\ \text { HVA/07 PAT } & \text { calcite } & \text { Patella shell } & \text { Present } & 0.709221 \\ \end{array}$

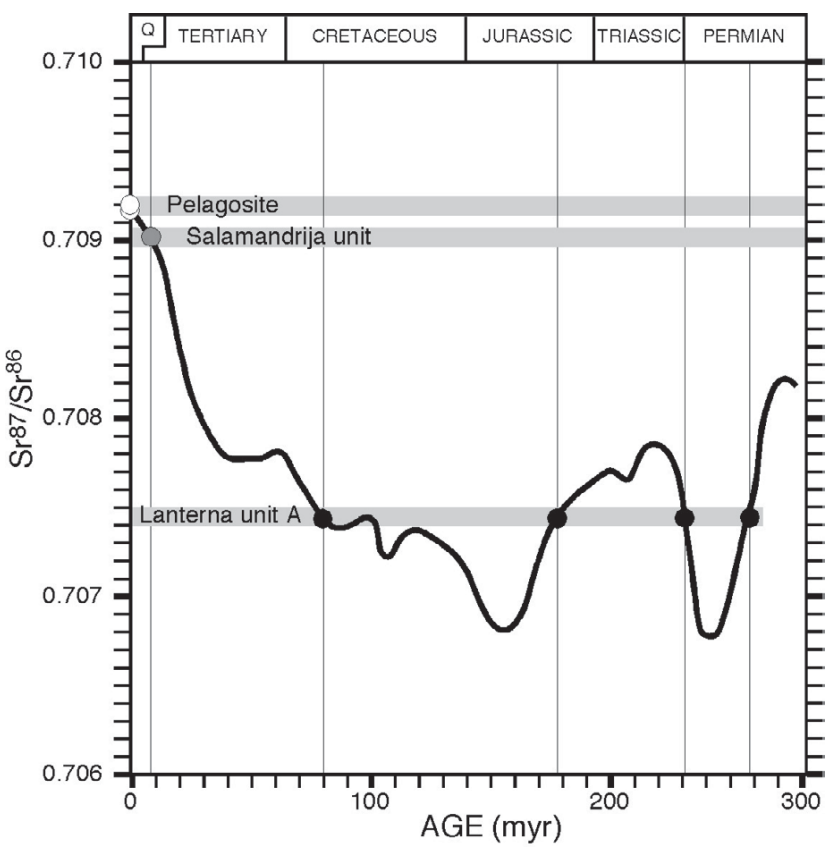

Figure 11: Plot of the ${ }^{87} \mathrm{Sr} /{ }^{86} \mathrm{Sr}$ composition of samples from the Lanterna unit A (dolomite), the Salamandrija unit (biocalcarenite), pelagosite (bioaragonite), and modern Adriatic gastropod shells compared to the Permian to Present seawater ${ }^{87} \mathrm{Sr} /{ }^{86} \mathrm{Sr}$ curve of MCARTHUR et al., 2001.

minifera, which indicate a broadly Neogene age (section 3.3.1., Fig. 10). Combining the biostratigraphic data with the chemostratigraphy (section 3.3.2.; Fig. 11) a broadly Miocene age is proposed here for the Salamandrija unit.

\subsection{Talus units and rock falls}

The stratigraphic succession making up the bedrock of Velika Palagruža is covered, particularly in the central part of the island, by loose or locally cemented talus, including breccia, rock-fall boulders, and soil. In the area of Stara Vlaka, a wedge of dip-slope, coarse, poorly cemented detritus covers up the dolomites of the Lanterna unit B. A cross section of the wedge and the underlying bedrock is exposed in the Stara Vlaka cove (Fig. 6A), offering the opportunity to determine the relationship between the cover and the underlying bedrock. Here, the dolomitic breccias of the Lanterna unit B are strongly tectonized, and displaced by the WNWESE striking oblique-slip fault, which puts them in contact with the equally tectonized Žalo unit (Fig. 6B). The fault as well as the contact between the Žalo unit and the Lanterna unit $\mathrm{A}$ is capped by the detrital wedge, which clearly dips
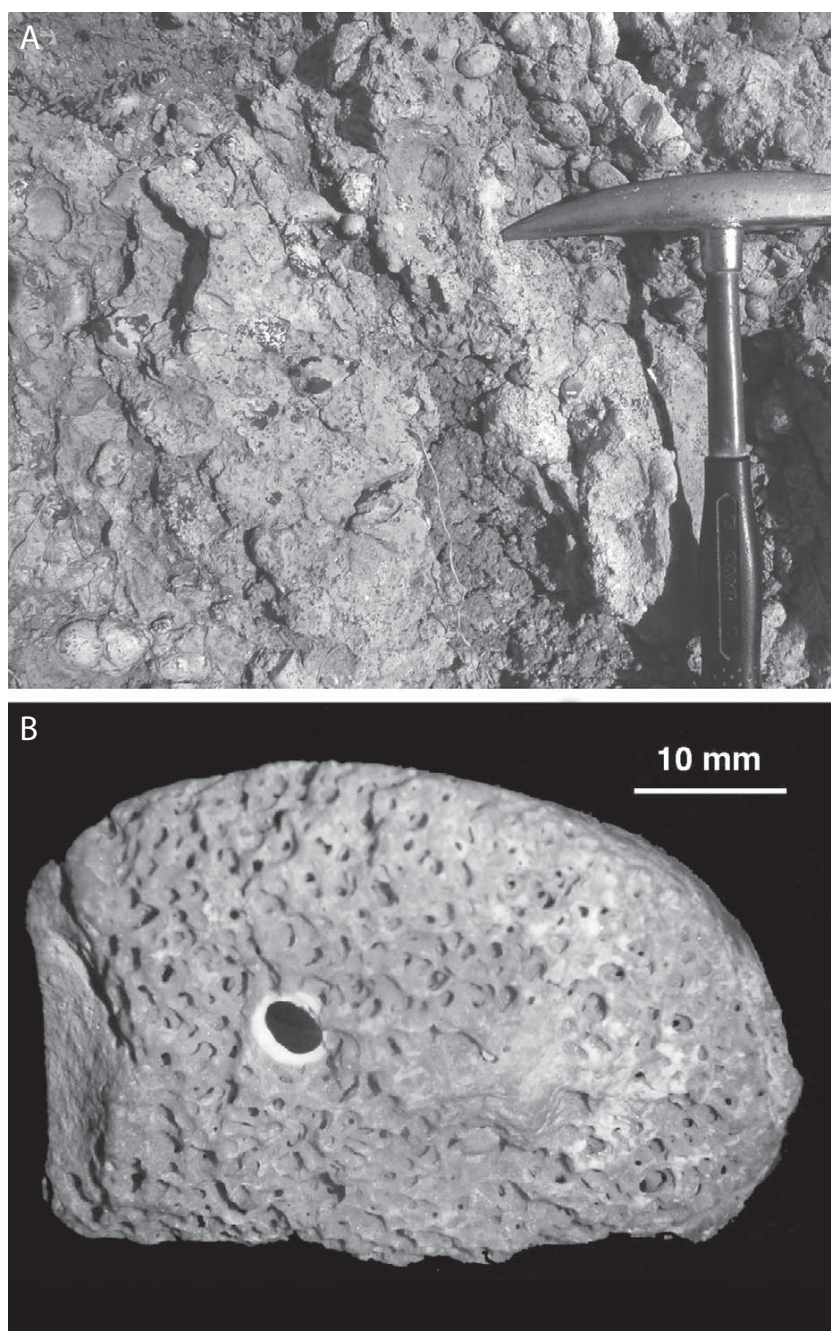

Figure 12: A) Outcrop of the pebbly palaeobeach of Stara Vlaka: B) a rounded pebble showing the surface perforated by burrowing algae and Lithodomus.

downslope toward the NE. The wedge is composed of layers of poorly cemented dolomite breccia resting on top of finer, reddish debris, probably representing a lateritic soil.

Near the contact with the underlying dolomite bedrock, at $13 \mathrm{~m}$ asl, a deposit of rounded pebbles suspended in a reddish sandy matrix (Fig. 12A) occurs. In between the pebbles, rare fragments of bivalve shells and pebbles showing the typical superficial texture produced by perforating algae suggest a palaeobeach depositional environment. One pebble we collected is perforated by a lithodomus burrow, which still contains the original bivalve shell (Fig. 12B). 
It is uncertain whether this deposit represents the remnant of a Quaternary palaeobeach or an older deposit formed during a Miocene transgression or Pliocene(?) to Quaternary marine regressions (i.e., during the emergence of the island). As for the bedded talus, it appears that it formed in recent times after the emersion of the island, and it does not represent a sedimentary continuation of the Salamandrija unit.

A similar talus exposure, which suggests a post-Miocene, post-deformational talus deposit, is observed on the west side of the Picokare ravine (see Fig. 4A). Here the poorly cemented breccia layers dip south, thus representing a talus slope with a bedding direction essentially perpendicular to the Salamandrija unit and the Stara Vlaka talus wedge. It is worth mentioning that just below the saddle between Salamandrija and the lighthouse peak, at about $50 \mathrm{~m}$ asl at the head of the Picokare ravine, we found some sparse rounded pebbles, which may represent yet another, older paleobeach deposit.

The slope on the south side of Salamandija, between Žalo and Picokare, is littered by loose rock waste and boulders, some of which are so large that they may in fact represent bedrock remnants of a strongly eroded cliff topography. It is also to be noted that, it has been reported that catastrophic rock falls occurred in very recent times (FORENBAHER \& KAISER, 2005).

\section{NEOTECTONICS AND RELATED FEATURES}

The island of Velika Palagruža can be described as a vertical topographic feature, in which the bedrock has been emerging from the sea in response to active tectonics, and is affected by marine erosion. In Section 2 we reviewed the present seismotectonic situation of the central Adriatic, which places Palagruža near the emergence of a large, seismically active thrust fault (BENNETT et al. 2008), and/or in an area where wrench tectonics and salt diapirism causes uplifting (e.g. GRANDIĆ et al., 2002; GELETTI et al., 2008). While surveying the island in recent years, several features were discovered, which testify to the recent uplifting of the island. These are flat areas (marine straths), palaeobeach deposits, and pelagosite, all occurring at different elevations throughout the island.

\subsection{Marine straths}

There are only few places where the topography is flat at Palagruža, which contrasts with the otherwise vertical topography of the island. These areas may represent marine straths (see Fig. 2 for locations). Of course, in this tiny island there are no extensive flat surfaces that may strictly be defined as a marine strath or peneplain. Thus, we use here the term of marine strath in a general sense, indicating a flat and nearly horizontal erosional surface cutting across steeply dipping bedrock layers.

One such marine strath is found at about $75 \mathrm{~m}$ asl, just above the Biljovka cove (Figs. 6A and 13A). Another possible case of marine strath is represented by Salamandrija, which is the largest flat area of the island at about $60 \mathrm{~m}$ asl, and, in fact, this has been the site of human settlements since the Early Neolithic (FORENBAHER \& KAISER, 2005).
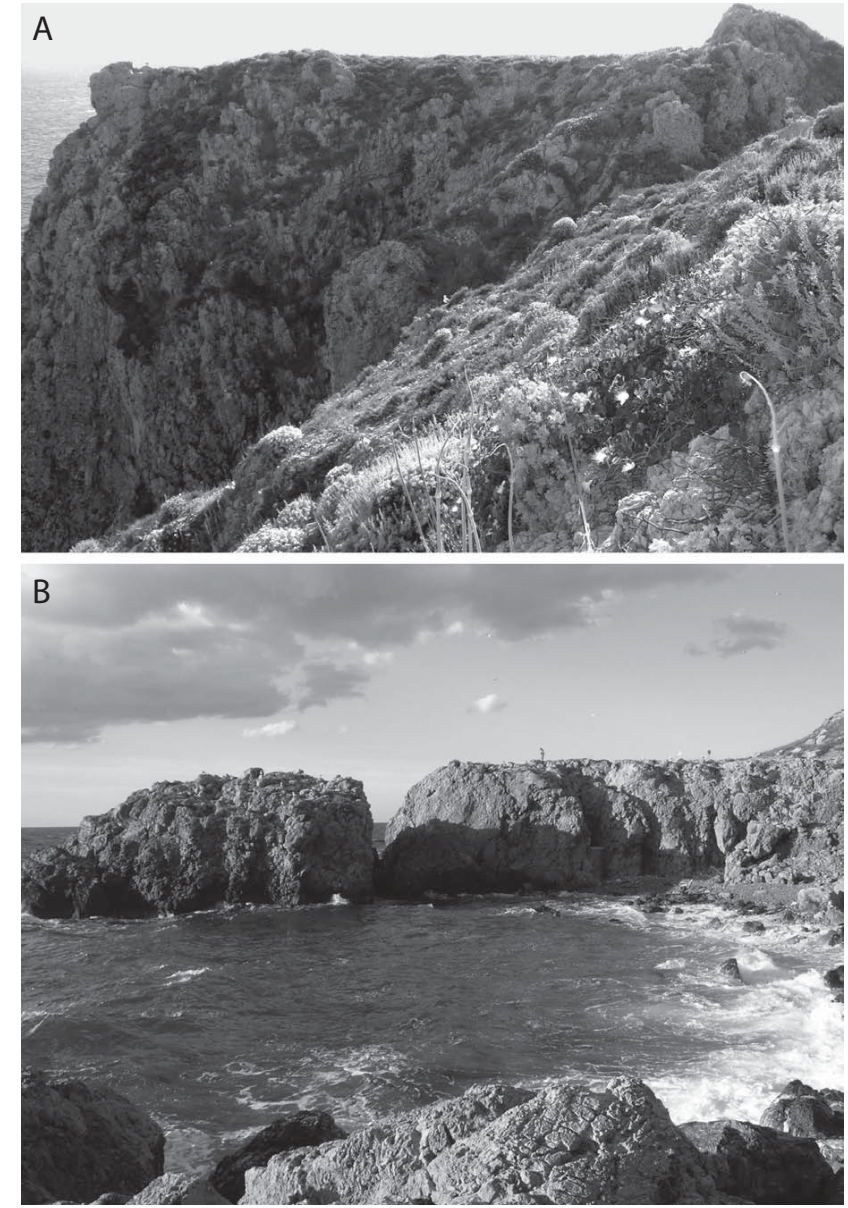

Figure 13: Marine straths A) at $75 \mathrm{~m}$ above sea level above the Biljovka cove, and B) making up the northern spur of Stara Vlaka cove.

Similarly, the archaeological site of Jonkova Njiva (about 50 $\mathrm{m}$ asl) on the eastern end of the island, and a small flat area at about the same elevation on the westernmost point of the island may also be considered remnants of flat erosional surfaces. Finally, the rocky promontory composed of dolomite breccia of the Lanterna unit B, which delimits the northern side of Stara Vlaka cove, is also cut by a flat and nearly horizontal surface, at about $13 \mathrm{~m}$ asl (Fig. 13B). This plateau is now covered in part by large rock-fall boulders, but in its inland part is overlain by the palaeobeach deposit.

\subsection{Palaeobeach deposits}

One palaeobeach deposit made up of rounded pebbles is described in Section 3.4. (Fig. 12A). A relatively conspicuous beach deposit is found at the western foot of the Picokare ravine resting at about $6 \mathrm{~m}$ asl, and consisting of rounded pebbles, cobbles, and boulders (up to $40 \mathrm{~cm}$ in diameter) free of any matrix (Fig. 14). Some pebbles exhibit a perforated surface possibly caused by burrowing algae or lithophagous bivalves, but no shells, nor encrusting algal remains have been found so far. A deposit of rounded pebbles was observed filling a ledge on the vertical sea cliff just above the palaeobeach deposit of Picokare, at about $13 \mathrm{~m}$ asl (Fig. 14).

Although the boulders could be deposited $6 \mathrm{~m}$ asl from the recent shoreline by gigantic waves under specific hydro- 


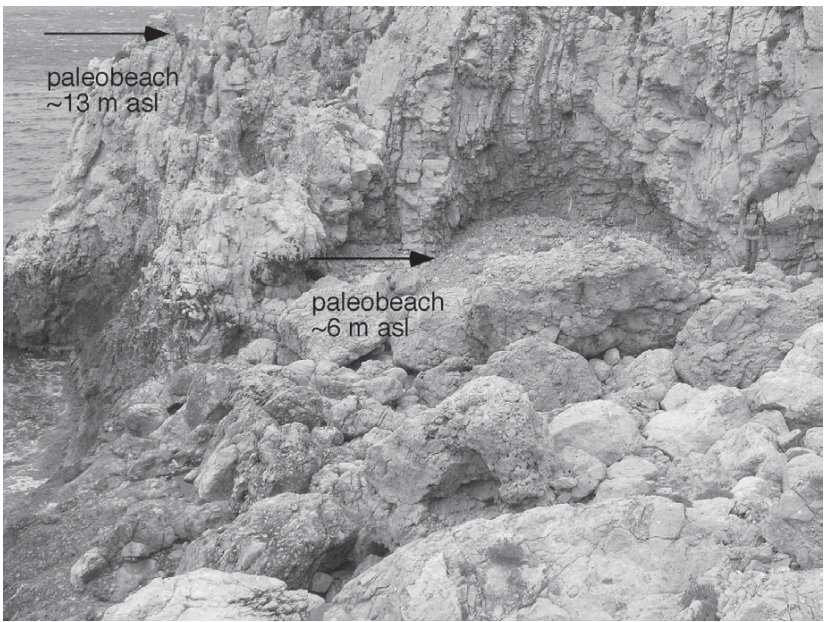

Figure 14: Subvertical bedding of the dolomites of the Lanterna unit A exposed along the littoral cliff of Picokare. Pebbly palaeobeach deposits at the bottom of the Picokare ravine (at about $6 \mathrm{~m}$ asl) and in a ledge of the cliff at about $13 \mathrm{~m}$ asl.

dynamic regimes, the deposit was still interpreted as a remnant of a palaeobeach, since in the footwall of the cliff pebbly beach deposits have not been observed. Thus, the palaeobeach also indicates recent uplifting of the island.

Unfortunately there are no means to determine an age for these palaeobeach deposits due to the absence of fossil remains. A more thorough survey of the cliffs around the lighthouse peak may reveal other deposits of this kind at different elevations, and chances are that fossil remains of sea molluscs can be found, providing material for radioisotopic dating.

\subsection{Pelagosite}

Further evidence for the recent tectonic uplifting of Palagruža comes from black mineral incrustations with a vitreous lustre resembling tar, which covers, in irregular patches, the rocky coast of the island from just above the tide line up to $13 \mathrm{~m}$ asl (Fig. 15A). This strange substance was first reported by MARCHESETTI (1876), and, one year later, it was named "pelagosite" (from Pelagosa, the Latin name of Palagruža) by STOSSICH (1877).

The reports by Marchesetti and Stossich were followed by 50 years of debate in the international scientific community about the nature and origin of this strange mineral (e.g. CLOËZ, 1878; SQUINABOL \& ONGARO, 1901; CLERICI, 1920). Finally, ONORATO (1926) published a comprehensive paper on the morphological, mineralogical, physical, chemical, and microbiological characteristics of pelagosite samples from the Tremiti islands, which are located some $75 \mathrm{~km}$ southwest of Palagruža. Pelagosite turned out to be pisolitic aragonite. It consists of pearl or mamellon-shaped objects with a concentric ring internal structure "similar to tree rings", made of a pure aragonite, and solidly attached to the rocky substratum. According to ONORATO (1926), pelagosite is produced by "blue-green algae" (i.e., cyanobacteria) where the supralittoral rock is frequently wetted by sea aerosol.

Optical microscopy by MONTANARI et al. (2007) confirmed the pisolitic structure of pelagosite, as originally ob- served by ONORATO (1926), and showed that 2-3 $\mu \mathrm{m}$ thick alternating dark-light laminae are arranged rhythmically through mm-thick sections of pelagosite crusts (Fig. 15B). Thicker laminae contain submicron-size inclusions of organic matter (Fig. 15C), including fragments of cyanobacterial cells (Fig. 15D) similar to those observed by ONORATO (1926) in the Tremiti pelagosite. By assuming that these laminae represent yearly accretions (just like the rings in a tree trunk), MONTANARI et al. (2007) determined that their arrangement bears cyclicity with frequencies comparable to those of the periodic climate changes controlled by El Nińo and the North Atlantic Oscillation (i.e., dry-wet/cold-warm meteorologic conditions alternating approximately every 3 , 8 , and 12 years).

In a recent microbiological study of pelagosite samples from Palagruža, MACALADY et al. (2008) confirmed Onorato's conclusion of a biogenic origin for this aragonite and, through DNA analysis of the organic fraction, they determined the presence of cells belonging to Xenococcus (Fig. $15 \mathrm{D})$, a rare genus of cyanobacteria, and apparently a new species never described before.

The fact that pelagosite apparently forms within a couple of metres above tide line, but today is found up to $13 \mathrm{~m}$ above sea level, suggests that Palagruža is currently uplifting. The uplifting rate of the Gargano promontory (Apulia domain, Fig. 1), estimated by MASTRONUZZI \& SANSÒ (2002) from U/Th dating of bioherms and other paleo-sea level indicators, is $1.5 \mathrm{~mm} \mathrm{yr}^{-1}$. In contrast, the coastal areas of NE Adriatic (Croatia) are presently under a regime of subsidence (BENAC et al., 2004; ANTONIOLI et al., 2007).

The preliminary U/Th dating of pelagosite from Velika Palagruža by MONTANARI et al. (2007), yielded ages around 2200 years for samples collected between 3 and $4 \mathrm{~m}$ above sea level at Picokare, and 6500 years for a sample from $6 \mathrm{~m}$ above sea level, suggesting that Palagruža is uplifting at a rate comparable with the uplifting rate of the Gargano promontory estimated by MASTRONUZZI \& SANSÒ (2002). This encourage further work to better evaluate the potential of this biomineral for assessing vertical tectonic movements of littoral environments.

\section{SUMMARY AND CONCLUSIONS}

The tiny islands of the Palagruža archipelago represent the only pieces of dry land exposed in the middle of the central Adriatic Sea. The outcrops offer the unique opportunity to study Mesozoic and Cenozoic deposits in the central part (Mid-Adriatic ridge) of the common Adriatic foreland of the Apenninic and Dinaridic orogenic domains. Our geological reconnaissance of the island of Velika Palagruža, the largest in the archipelago, allows us to assess some stratigraphic and tectonostructural characteristics, which were never described in the few geological reports available in accessible literature.

Velika Palagruža is composed of four main sedimentary units. However, evidence that these units are in stratigraphic continuity is lacking, as they are all bounded by faults and discordances. 

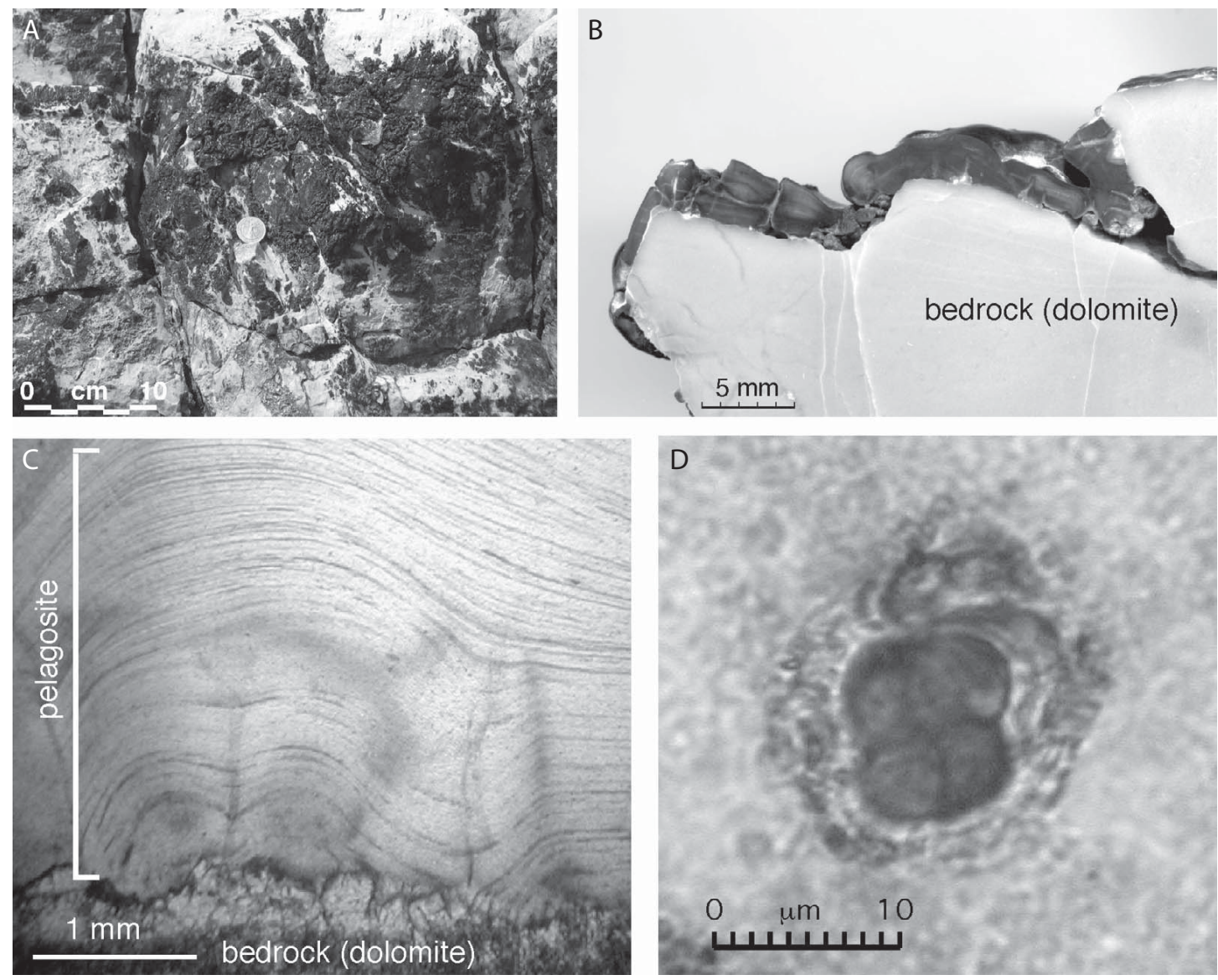

Figure 15: A) Pelagosite encrustations on the cliff near Picokare at about $4 \mathrm{~m}$ above sea level; B) polished section of a pelagosite crust; C) thin section microphotograph (transmitted plain light) of a pelagosite crust from Picokare showing a rhythmic microlaminar arrangement; D) a cell of cyanobacterium Xenococcus extracted from pelagosite.

The oldest unit recognized is formed of highly deformed siliciclastic (silt and clay) deposits containing gypsum and thin layers of stromatolitic limestones capped by a package of thin-bedded dolomite layers. Palynomorphs contained in the clay at the base of this succession indicate a Middle Triassic age (Ladinian). This unit, named Žalo, represents a transitional fluvial-to-shallow marine, occasionally evaporitic environment, typical of the Middle Triassic rifting phase of the Adriatic microplate.

The Žalo unit is in discordant relationship with the younger Lanterna unit of thick to medium-thick bedded dolomite and dolomite breccia, with or without chert. Palynomorphs in a sample from the Lanterna unit indicate a Late Triassic age. The Lanterna unit is actually made up of two subunits recognizable for their different bedding thickness and style. Unit A is characterized by thick and medium-thick layers of dolomite with chert, and unit $\mathrm{B}$ is characterized by massive dolomite breccia and thin- to medium-thick dolomite layers devoid of chert. These two subunits are separated by a WNWESE striking, subvertical, oblique-slip fault, which crosses the entire length of the island. The presence of well-bedded dolomite with chert and massive bodies of dolomite breccia suggests a transitional platform-to-basin depositional setting of an evolving Adriatic Basin domain.

The Lanterna unit dolomites are capped by biocalcarenites of the Salamandrija unit, containing abundant microfos- sils, which, along with strontium isotope data, indicate a broadly Miocene age. The biocalcarenites bedding alignment is highly discordant in respect to the underlying Lanterna unit, although the actual contact between the two units is not visible because it is covered by talus. Talus, landslide deposits, and humic soil make up the cover of the bedrock sedimentary succession of the island, and they represent the ultimate phase of emergence of the island, which probably occurred during Pliocene? to Quaternary times.

The bedrock units of Velika Palagruža, each one displaced by faults and/or in diapiric contact to each other, and therefore not in stratigraphic continuity, represent just a few pieces of a large and complicated puzzle depicting the tectono-sedimentary evolution of the central Adriatic basin. The almost perpendicular discordance (unconformity?) separating the Salamandrija unit from the underlying Triassic dolomites suggests a deformational phase preceding Miocene marine deposition, perhaps a marine transgression over an already deformed and eroded dolomite massif. The WNW-ESE striking subvertical oblique-slip fault that crosses the entire length of the island is probably still active. Soft and strongly deformed Ladinian siliciclastic-evaporitic Žalo unit deposits occur along the fault, and may be related to diapirism.

The central Adriatic area is under an active seismic regime. Recent uplifting of Velika Palagruža is shown by remnants of pebbly palaeobeach deposits, marine (erosional) 
straths, and cyanobacterial supratidal encrustations (pelagosite) today found at various elevations above mean sea level. Further detailed research on the structural geology, stratigraphy, micropalaeontology, and radioisotope geochronology will hopefully add detailed constraints in a more accurate reconstruction of the geologic and tectonic history of the Palagruža archipelago.

\section{ACKNOWLEDGEMENT}

We would like to thank Dr. Branko KIRIGIN, and his team of archaeologist researchers, for introducing us to Palagruža and its marvels, and for supporting us with the logistics while surveying the island in several expeditions between 2005 and 2007. We thank Ross MITCHELL, Maxwell MONTANARI, Elisabetta FERRONI, and Markus FIEBIG for assistance during fieldwork in several separate expeditions. We are also grateful to Matteo D'AMATO and Mislav for having given us a ride with their fast boats to the island in the expedition of October 2005. We like to thank Simone GALEOTTI and Vincenzo PICOTTI for a preliminary microfossil identification of the Salamandrija biocalcarenite. The sulphur analyses were undertaken at the University of Leeds S Isotope Facility thanks to the help of Rob NEWTON. Careful reviews by Igor VLAHOVIĆ, Simonetta CIRILLI, and Mladen JURAČIĆ, which significantly improved the quality of the paper, are greatly acknowledged. This study was partly supported by the project "Stratigraphy and Geodynamic Context of Cretaceous Deposits in the NE Adriatic Region" no. 181-1191152-2697 of the Ministry of Science, Education and Sports of the Republic of Croatia.

\section{REFERENCES}

ADLOFF, M.C., APPIA, C., DOUBINGER, J. \& LIENHARDT, M.J. (1984): Zonation palynostratigraphiques dans les séries triasique traversées par de sondage le Jura et le Bas-Dauphiné.- Géol. Fr., 1, $3-21$.

ADLOFF, M.C., DOUBINGER, J., MASSA, D. \& VACHARD, D. (1986): Trias de Tripolitaine (Lybie). Nouvelles données biostratigraphiques et palynologiques. Deuxičme partie. Rev. Inst. Fr. Pe., $41,27-72$.

AGIP (1982): Foraminiferi Padani (Terziario e Quaternario).- Atlante iconografico e distribuzioni stratigrafica. $2^{\text {nd }}$ edition, $52 \mathrm{pls}$.

ANTONIOLI, F., ANZIDEI, M., LAMBECK, K., AURIEMMA, R., GADDI, D., FURLANI, S., ORRŮ, P., SOLINAS, E., GASPARI, A., KARINJA, S., KOVAČIĆ, V. \& SURACE, L. (2007): Sea-level change during the Holocene in Sardinia and in the northeastern Adriatic (central Mediterranean Sea) from archaeological and geomorphological data.- Quarter. Sci. Rev., 26, 2463-2486. doi: 10. 1016/j.quascirev.2007.06.022

BATTEN, D.J. (2002): Palynofacies and palaeoenvironmental interpretation.- In: JANSONIUS, J. \& MCGREGOR, D.C. (eds.), $2^{\text {nd }}$ edition, Palynology: Principles and Applications. AASP Foundation, 3, 1011-1064.

BATTAGLIA, M., MURRAY, M.H., SERPELLONI, E. \& BÜRGMANN, R. (2004): The Adriatic region: An independent microplate within the Africa-Eurasia collision zone.- Geophy. Res. Lett., 31, L09605. doi:10.1029/2004g1019723.

BELAK, M., KOCH, G., GRGASOVIĆ, T., VLAHOVIĆ, I., VELIĆ, I., SOKAČ, B. \& BENČEK, Đ. (2005): Novi prinosi stratigrafiji evaporitno-karbonatno-klasatično-vulkanogenog kompleksa Komiškog zaljeva (otok Vis, Hrvatska) [New Contribution to the Stratigraphy of Evaporitic-Carbonate-Clastic-Volcanogenic Complex of Komiža Bay (Island of Vis, Croatia) - in Croatian].- In: VELIĆ, I., VLAHOVIĆ, I. \& BIONDIĆ, R. (eds.): 3. Hrvatski geološki kongres, ( $3^{\text {rd }}$ Croatian Geological Congress), Opatija 29.09.-01.10. 2005., Knjiga sažetaka (Abstract Book), Hrvatski geološki institut - Croatian Geological Survey, Zagreb, 13-14.
BENAC, Č., JURAČIĆ, M. \& BAKRAN-PETRICIOLI, T. (2004): Submerged tidal notches in the Rijeka Bay NE Adriatic Sea: indicators of relative sea-level change and of recent tectonic movements.Mar. Geol., 212, 21-33. doi: 10.1016/j.margeo.2004.09.002

BENNETT, R.A., HREINSDÓTTIR, S., BUBLE, G., BAŠIĆ, T., BAČIĆ, Ž., MARJANOVIĆ, M., CASALE, G., GENDASZEK, A. \& COWAN, D. (2008): Eocene to present subduction of southern Adria mantle lithosphere beneath the Dinarides.- Geology, 36/1, 3-6. doi: 10.1130/G24136A.1

BERTINELLI, A., CIARAPICA, G. \& PASSERI, L. (2005): Late Triassic-Jurassic basinal successions in Molise and northern Basilicata: the northernmost witness of the Ionian Ocean.- Boll. Soc. Geol. It., 124, 177-188.

BERTOTTI, G, PICOTTI, V., CHILOVI, C., FANTONI, R., MERLINI, S. \& MOSCONI, A. (2001): Neogene to Quaternary sedimentary basins in the south Adriatic (Central Mediterranean): Foredeeps and lithospheric buckling.- Tectonics, 20/5, 771-787.

BESEMS, R.E. (1983): Aspects of Middle and Late Triassic palynology. 3. Palynology of the Hornos-Siles Formation (Prebetic Zone, Province of Jaén, Southern Spain) with additional information on the macro- and microfaunas.- Österreich. Akad. Wissensch. Schriftenr. Erdwissensch. Komm., 5, 37-56.

BEUTLER, G., HEUNISCH, C., LUTTPOLD, F.W., RETTIG, B. \& RÖHLING, H.-G. (1996): Muschelkalk, Keuper und Lias am Mittellandkanal bei Sende (Niedersachsen) und die regionale Stellung des Keupers.- Geol. Jb., A 145, 67-197.

BLENDINGER, E. (1988): Palynostratigraphy of the Late Ladinian and Carnian in the Southern Dolomites.- Rev. Palaeobot. Palynol., 53, 329-348. doi: 10.1016/0034-6667(88)90038-3

BOGNAR, A. (1995): Geomorphological characteristics of the Palagruža Archipelago: in Palagruža the Pearl of the Adriatic.- Proceeding of the Croatian Meterological Society, Split, 87-95.

BOLTOVSKOY, E. \& WRIGHT, R. (1976): Recent Foraminifera.- The Hague, Dr. W. Junk b.v. Publishers, 515 p.

BOSELLINI, A. (2002): Dinosaurs "re-write" the geodynamics of the eastern Mediterranean and paleogeography of the Apulia Platform.Earth-Sci. Rev., 59/(1-4), 211-234. doi: 10.1016/S0012-8252(02) 00075-2

BOŽIČEVIĆ, S., MULDINI-MAMUŽIĆ, S. \& VRSALOVIĆ-CAREVIĆ, I. (1965): The sedimentary-petrographic and palaeontologic characteristics of the insular group of Palagruža.- Bull. Acad. Council Sci. RSF Yugoslavia, Section A, Zagreb, 10, 66-67.

BRACK, P., RIEBER, H., NICORA, A. \& MUNDIL, R. (2005): The Global boundary Stratotype Section and Point (GSSP) of the Ladinian Stage (Middle Triassic) at Bagolino (Southern Alps, Northern Italy) and its implication for the Triassic time scale.- Episodes, 28, 233-244.

BROGLIO LORIGA, C., CIRILLI, S., DE ZANCHE, V., DI BARI, D., GIANOLLA, P., LAGHI, G.F., LOWRIE, W., MANFRIN, S., MASTANDREA, A., MIETTO, P., MUTTONI, G., NERI, C., POSENATO, R., RECHICHI, M., RETTORI, R. \& ROGHI, G. (1999): The Prati di Stuores/Stuores Wiesen Section (Dolomites, Italy): A Candidate Global Stratotype Section and Point for the Base of the Carnian Stage.- Riv. Ital. Paleontol. Stratigr., 105, 37-78.

BRUGMAN, W.A. (1986): Palynological characterization of the Upper Scythian an Anisian of the Trans-Danubian Central Range (Hungary) and the Vicentinian Alps (Italy).- Unpubl, PhD. Thesis, University of Utrecht, $95 \mathrm{p}$.

BRUGMAN, W.A., VELD, H., VAN BUGGENUM, J.M., HOLSHUIJSEN, R.P., BOEKELMAN, W.A., VAN DEN BERGH, J.J., ALMEKINDERS, M.P., POORT, R.J., ABBINK, O.A. \& D'ENGELBRONNER, E.R. (1988): Palynological investigation within the Triassic of the Germanic Basin of Southern Germany.Stuifmail, 6, 52-54. 
BRUGMAN, W.A., VAN BERGEN, P.R. \& KERP, J.H.F. (1994): A quantitative approach to Triassic palynology, the Lettenkeuper of the Germanic Basin as an example.- In: TRAVERSE, A. (ed.): Sedimentation of Organic Particles. Univ. Press Cambridge, 409-429.

BRÜHWILER, T., HOCHULI, P.A., MUNDIL, R., SCHATZ, W. \& BRACK, P. (2007): Bio- and chronostratigraphy of the Middle Triassic Reifling Formation of the westernmost Northern Calcareous Alps.- Swiss J. Geosci., 100, 443-455. doi: 10.1007/s00015-007$1240-2$

CHANNELL, J.E.T., D'ARGENIO, B. \& HORVATH, F. (1979): Adria, the African promontory, in Mesozoic Mediterranean palaeogeography.- Earth-Sci. Rev., 15, 213-292. doi: 10.1016/0012-8252(79) 90083-7

CHIARABBA, C., JOVANE, L. \& DISTEFANO, R. (2005): A new view of Italian seismicity using 20 years of instrumental recordings.Tectonophys., 395, 251-268. doi: 10.1016/j.tecto.2004.09.013

CLERICI, E. (1920): Pelagosite di Canalgrande nell'Inglesiente.- Rendiconti dell'ccademia dei Lincei, Serie 5, Fascicolo 11.

CLOËZ, S. (1878): Note sur une matičre minérale d'apparance vitreuse, qui se depose sur la roche littoral de la Méditerranée.- Bull. Soc. Géol. France, 6, 84.

COURTINAT, B. \& RIO, M. (2004): The Statistical analysis of palynofacies of the Ladinian strata of the South east Massif central, France (Analyse statistique de palynofacičs des dépôts ladinien du SE du Massif central français).- Rev. Micropal., 47, 28-35. doi: 10.1016/ j.revmic.2004.01.002

CROS, P. \& DOUBIGNER, J. (1982): Étude palynologiques de sédiments terrigčnes et pélagique du Trias moyen des Dolomites italiennes. Relation avec la paléonvironnement.- Sci. Géol. Bull., 35, $157-182$.

DePAOLO, D.J. \& INGRAM, B.L. (1985): High-resolution stratigraphy with strontium isotopes.- Science, 227, 938-941. doi: 10.1126/science.227.4689.938

ESHET, Y. (1990): Paleozoic-Mesozoic Palynology of Israel. 1. Palynological Aspects of the Permo-Triassic Succession in the Subsurface of Israel.- Geol. Surv. Isr. Bull., 81, 1-57.

FORENBAHER, S. \& KAISER, T. (2005): Palagruža i širenje zemljoradnje na Jadranu (Palagruža and the spread of the farming in the Adriatic).- Opvscula Archaeologica, 29, 7-23.

GARCIA GIL, S. \& DIEZ, J.B. (2006): Microflora of the "Muschelkalk Sedimentary Cycle" in the NW Iberian Range, Central Spain.- $7^{\text {th }}$ European Palaeobotany-Palynology Conference, September 6-11, Praque, Program and Abstracts, 47.

GELETTI, R., DEL BEN, A., BUSETTI, M., RAMELLA, R. \& VOLPI, V. (2008): Gas seeps linked to salt structures in the Central Adriatic Sea.- Basin Res., 20, 473-487. doi: 10.1111/j.1365-2117. 2008.00373.x

GÓCZÁN, F. \& ORAVECZ-SCHEFFER, A. (1993): The Anisian/Ladinian Boundary in the Transdanubian Central Range based on palynomorphs and foraminifers.- Acta Geol. Hung., 36, 73-143.

GORIČAN, Š., HALAMIĆ, J., GRGASOVIĆ, T. \& KOLARJURKOVŠEK, T. (2005): Stratigraphic evolution of Triassic arcbackarc system in northwestern Croatia.- Bull. Soc. Géol. France, 176, 3-22. doi: 10.2113/176.1.3

GRANDIĆ, S., BOROMISA-BALAŠ, E., ŠUŠTERČIĆ, M. (1997): Exploration concept and characteristics of the stratigraphic and structural models of the Dinarides in Croatian offshore area.- Nafta, 48/8-9, 249-266.

GRANDIĆ, S., BIANCONE, M. \& SAMARŽIJA, J. (2002): Geophysical and Stratigraphic Evidence of the Adriatic Triassic Rift Structures.- Mem. Soc. Geol. It., 57, 315-325.

GRGASOVIĆ, T. \& SOKAČ, B. (2003): Review on fossil dasycladalean associations in the Triassic of Croatia.-Acta Micropalaeont. Sinica, 20/1, 75-79.
HERAK, M., HERAK, D. \& MARKUŠIĆ, S. (1996): Revision of the earthquake catalogue and seismicity in Croatia (1908-1992).- Terra Nova, 8, 86-96. doi: 10.1111/j.1365-3121.1996.tb00728.x

HEUNISCH, C. (1986): Palynologie des unteren Keupers in Franken süd Deutschlands.- Palaeontographica B, 200, 33-110.

HEUNISCH, C. (1999): Die Bedeutung der Palynologie für Biostratigraphie und Fazies in der Germanischen Trias.- In: HAUSCHKE, N. \& WILDE, V. (eds.): Trias. Eine ganz andere Welt. Mitteleuropa im frühen Erdmittelalter. Verlag Dr. Friedrich Pfeil, München, 207-220.

HOCHULI, P.A. \& ROGHI, G. (2002): A palynological view on the Anisian/Ladinian boundary - new results from the Seceda section (Dolomites, Northern Italy).- I.U.G.S. Commission on Triassic Stratigraphy, STS/IGCP 467, Field Meeting, Veszprém, Hungary, 5-8 September 2002, Geological Institute of Hungary, Program and Abstracts, 29-30.

KIRIGIN, B. \& ČAČE, S. (1998): Archaeological evidence for the cult of Diomedes in the Adriatic.- Hesperia, 9, 63-110.

KOROLIJA, B., BOROVIĆ, I., GRIMANI, I., MARINČIĆ, S., JAGAČIĆ, T., MAGAŠ, N. \& MILANOVIĆ, M. (1977): Osnovna geološka karta SFRJ 1:100 000. Tumač za Lastovo, Korčulu i Palagružu, K 33-46, K 33-47 i K 33-57. [Basic Geological Map of SFRY 1:100 000, Geology of the Lastovo, Korčula and Palagruža sheets - in Croatian]. Institut za geološka istraživanja, Zagreb, Savezni geolški zavod, Beograd, $53 \mathrm{p}$.

KOVÁCS, S., DOSZTÁLY, L., GÓCZÁN, F., ORAVECZ-SCHEFFER, A. \& BUDAI, T. (1994): The Anisian-Ladinian boundary in the Balaton Highland, Hungary - a complex microbiostratigraphic approach--Albertiana, 14, 53-64.

LUČIĆ, D., KOCH, G., FORŠEK, G., MARETIĆ, S., BALAŽBOROMISA, E., KRIZMANIĆ, K., ŠPANIĆ, D., MESIĆ, I. \& BUBNIĆ, J. (2003): Lithofacies, palynofacies and organic facies of Triassic evaporitic-carbonate succession: Examples from Croatian off-shore and Syrian on-shore wells. $-22^{\text {nd }}$ IAS Meeting of Sedimentology, Opatija. Abstracts Book, 111.

MACALADY, J.L., MONTANARI, A., BICE, D.M., SCHAPERDOTH, I., MACLEAN, L. \& MARIANI, S. (2008): Pelagosite climate record and the role of cyanobacterial biomineralization.-Geochim. Cosmochim. Acta, 72/2, A579.

MARCHESETTI, C. (1876): Descrizione dell'Isola di Pelagosa.- Boll. Soc. Adriatic. Sci. Nat., 2, Trieste, 283-306.

MARIANI, S., MAINIERO, M., BARCHI, M., VAN DER BORG, K., VONHOF, H. \& MONTANARI, A. (2007): Use of speleologic data to evaluate Holocene uplifting and tilting: an example from the Frasassi anticline (northeastern Apennines, Italy).- Earth Planet. Sci. Lett., 257, 313-318. doi: 10.1016/j.eps1.2007.02.045

MASTRONUZZI, G. \& SANSŇ, P. (2002): Holocene uplift rates and historical rapid sea-level changes at the Gargano promontory, Italy.- J. Quarter. Sci. 17, 593-606. doi:10.1002/jqs.720

McARTHUR, J.M., HOWARTH, R.J. \& BAILEY, T.R. (2001): Strontium Isotope Stratigraphy: LOWESS Version 3: Best fit to the marine Sr-Isotope Curve for 0-509 Ma and accompanying look-up table for deriving numerical age.- J. Geol., 109, 155-170. doi: $10.1086 / 319243$

MONTANARI, A., BICE, D., DRUSCHEL, G., MARIANI, S., MARSHALL, C., OLCOTT, A., SHARP, W., TIGUE, T. \& VUCETIĆ, M. (2007): Rediscovering pelagosite: a Mediterranean "microstromatolite" recording recent climate cycles.- Geophys. Res. Abstr., 9, 01555, 2007, SRef-ID: 1607-7962/gra/EGU2007-A-01555.

ONORATO, E. (1926): Sulla pelagosite delle Isole Tremiti nell'Adriatico.Boll. Soc. Geolog. Ital., 45, 17-31.

ORŁOWSKA-ZWOLIŃSKA, T. (1983): Palinostratygrafia epikontynentalnych osadów wyższego triasu w Polsce (Palynostratigraphy of the upper part of Triassic epicontinental sediments in Poland).Pr. Inst. Geol., 104, 1-89. 
REITZ, E. (1985): Palynologie der Trias in Nordhessen und Südniedersachsen.- Geol. Abh. Hessen, 86, 1-36.

RIDENTE, D. \& TRINCARDI, F. (2006): Active foreland deformation evidenced by shallow folds and faults affecting late Quaternary shelf-slope deposits (Adriatic Sea, Italy).- Basin. Res., 18, $171-188$.

ROGHI, G. (2004): Palynological investigation in the Carnian of the Cave del Predil are (Julian Alps, NE Italy).- Rev. Palaeobot. Palynol., 132, 1-35. doi:10.1016/j.revpalbo.2004.03.001

SERVIZIO GEOLOGICO D'ITALIA (2007): Carta Geologica d'Italia 1:50.000 - Catalogo delle Formazioni Quaderni.- Serie III - Volume 7 - Fascicolo VII - Unitŕ tradizionali (2).

SCHEURING, B. (1978): Mikrofloren aus den Meridekalken des Monte San Giorgio (Kanton Tessin).- Schweiz. Paläont. Abh., 100, $1-205$.

SCHULZ, E. \& HEUNISCH, C. (2005): Palynostratigraphische Gliederungsmöglichkeiten des deutschen Keupers.- In: BEUTLER, G. (Coord.), Stratigraphie von Deutschland IV, Keuper. Cour. Forsch. Inst. Senckenberg, 253, 43-49.

SOKAČ, B., ŠČAVNIČAR, B. \& VELIĆ, I. (1980): Klastiti donjeg trijasa uz evaporite na otoku Velika Palagruža (Središnji Jadran) [The Lower Triassic clastics and the evaporites on the island of Velika Palagruža (Central Adriatic) - in Croatian ].- Geol. vjesnik, 32, 207-212.

SQUINABOL, S., \& ONGARO, G. (1901): Sulla pelagosite. - Riv. Mineralog. Cristallograf., 24, 44.

STACHE, G. (1876): Geologische Notizen über die Insel Pelagosa.- Verhandungen d. Geol. Reichsanst., 6, 123-127.

STOSSICH, M. (1877): Sulla geologia e zoologia dell'Isola di Pelagosa.- Boll. Soc. Adriatic. Sci. Nat., 3, Trieste, 186.

STUR, D. (1874): Tertiär petrefacte von der Insel Pelagosa in Dalmatien, eingesendetvon Herrn G. Buchich in Lesina.- Verhandlungen d. geol. Reichsanst., 391.

ŠIFTAR, D. (1987): Primjena izotopne analize sumpora u određivanju starosti anhidrita iz Jadranskog evaporitskog područja [The use of sulfur isotope analysis in the age determination of the Adriatic evaporitic area anhydrites - in Croatian].- Geol. vjesnik, 40, 65-74.

TARI, V. (2002): Evolution of the northern and western Dinarides: a tectonostratigraphic approach.- European Geosciences Union, Stephan Mueller Special Publication Series, 1, 223-236.
TYSON, R.V. (1995): Sedimentary organic matter. Organic facies and palynofacies.- Chapman and Hall, $591 \mathrm{p}$.

VAN BERGEN, P.F. \& KERP, J.H.F. (1990): Palynofacies and sedimentary environments of a Triassic section in southern Germany.- In: FERMONT, J.J. \& WEEGINK, J.W. (eds.): International symposium on organic petrology. Med. Rijks Geol. Dienst, 45, 23-39.

VAN DEN BERGH, J.J. (1987): Aspects of Middle and Late Triassic palynology. Palynologocal investigation in the Keuper (Upper Ladinian, Karnian, Norian and Rhaetian) and Lower Jurassic (Lias $\alpha 1$ $+\alpha 2$ ) of Franken, SE West-Germany.- Stuifmail, 5, 26-33.

VAN DER EEM, J.G.L.A. (1983): Aspects of Middle and Late Triassic palynology. 6. Palynological investigation in the Ladinian and Karnian of the Western Dolomites, Italy.- Rev. Palaeobot. Palynol., 39, 189-300. doi:10.1016/0034-6667(83)90016-7

VISSCHER, H. \& KRYSTYN, L. (1978): Aspects of Late Triassic palynology. 4. A palynological assemblage from the ammonoid-controled Late Karnian (Tuvalian) sediments of Sicily.- Rev. Palaeobot. Palynol., 26/ 1-4, 93-113. doi:10.1016/0034-6667(78)90007-6

VISSCHER, H. \& BRUGMAN, W.A. (1981): Ranges of selected palynomorphs in the Alpine Triassic of Europe.- Rev. Palaeobot. Palynol. 34, 115-128. doi: 10.1016/0034-6667(81)90069-5

VISSCHER, H. \& VAN DER ZWAN, C.J. (1981): Palynology of the Circum-Mediterranean Triassic: Phytogeographical and Palaeoclimatological Implications.- Geol. Rundsch., 70, 625-634. doi: 10. 1007/BF01822140

VISSCHER, H., VAN HOUTE, M., BRUGMAN, W.A. \& POORT, R.J. (1994): Rejection of a Carnian (Late Triassic) "pluvial event" in Europe.- Rev. Palaeobot. Palynol., 83, 217-226. doi: 10.1016/ 0034-6667(94)90070-1

VLAHOVIĆ, I., TIŠLJAR, J., VELIĆ, I., \& MATIČEC, D. (2005): Evolution of the Adriatic Carbonate Platform: Palaeogeography, main events and depositional dynamics.- Palaeogeog., Palaeoclimatol., Palaeoecol., 220/3-4, 333-360. doi: 10.1016/j.palaeo.2005.01.011

WARRINGTON, G. (2002): Triassic Spores and Pollen.- In: JANSONIUS, J. \& MCGREGOR, D.C. (eds.), $2^{\text {nd }}$ edition, Palynology: Principles and Applications. AASP Foundation, 2, 755-766.

YAROSHENKO, O.P. \& BASH IMAM, I. (1995): Age Variability of Palynomorph Compositions of the Middle and Late Triassic of Syria and their Relation to Climate and Facies.- Stratigr. Geo. Correl., 3, 375-392.

ZAPPATERRA, E. (1994): Source rock distribution model of the Periadriatic region.-AAPG Bull., 78/3, 333-354. 


\section{APPENDIX 1.}

\section{LIST OF AUTOCHTHONOUS LADINIAN \\ PALYNOMORPHS FROM THE ŽALO UNIT \\ CLAYSTONES (SAMPLE PAL-6, LOCATION 1 \\ ON FIG. 2)}

\section{Spores}

Calamospora tener (LESCHIK, 1955) MÄDLER, 1964a - 0.6\%

Calamospora keuperiana MÄDLER, 1964a - 0.6\%

Todisporites minor COUPER, $1958-\mathbf{0 . 2 \%}$

Todisporites major COUPER, $1958-\mathbf{0 . 2 \%}$

Todisporites cinctus (MALJAWKINA, 1964) ORŁOWSKAZWOLIŃSKA, $1971-\mathbf{0 . 4 \%}$

Deltoidospora minor (COUPER, 1953) POCOCK, $1970-\mathbf{0 . 2 \%}$

Concavisporites toralis (LESCHIK, 1955) NILSSON, $1958-\mathbf{0 . 8} \%$

Concavisporites crassexinius NILSSON, $1958-\mathbf{0 . 4 \%}$

Osmundacidites wellmanii COUPER, $1953-\mathbf{0 . 2 \%}$

Verrucosisporites morulae KLAUS, $1960-\mathbf{0 . 2 \%}$

Uvaesporites gadensis PRAEHAUSER-ENZENBERG, 1970 - 1.2\% Porcellispora longdonensis (CLARKE, 1965) SCHEURING, 1970-0.4\% Anapiculatisporites spiniger (LESCHIK, 1955) REINHARDT, 1961

$$
-1.4 \%
$$

Sellaspora rugoverrucata VAN DER EEM, 1983 - $\mathbf{0 . 2 \%}$

Kyrtomisporis ervei VAN DER EEM, 1983 - 1.4\% (Fig. 7/1)

Aratrisporites fimbriatus (KLAUS, 1960) MÄDLER, 1964a - 0.4\%

Leschikisporis aduncus (LESCHIK, 1955) POTONIÉ, 1958 emend. BHARADWAJ \& SINGH, $1964-\mathbf{0 . 4 \%}$

Pollen

Enzonalasporites sp.

Patinasporites sp.

Heliosaccus dimorphus MÄDLER, 1964b - 0.4\% (Fig. 7/4)

Cannanoropollis scheuringii BRUGMAN, 1986 - 1.4\% (Fig. 7/3)

Kuglerina meieri SCHEURING, $1978-\mathbf{0 . 8 \%}$

Doubingerispora filamentosa SCHEURING, 1978 - 0.2\% (Fig. 7/2)

Infernopollenites sulcatus (PAUTSCH, 1958), SCHEURING, 1970 $0.4 \%$

Lunatisporites acutus LESCHIK, 1955 emend. SCHEURING, 1970 4.2\% (Fig. 7/5)

Striatoabieites aytugii VISSCHER, 1966 emend. SCHEURING,1970 $-\mathbf{0 . 8 \%}$ (Fig. 7/6)

Striatoabieites balmei KLAUS, 1964 emend. SCHEURING, $1978-$ $4.6 \%$

Triadispora plicata KLAUS, $1964-\mathbf{0 . 4 \%}$ (Fig. 7/7)

Triadispora crassa KLAUS, $1964-\mathbf{0 . 4 \%}$

Triadispora stabilis SCHEURING, 1970 emend. SCHEURING, 1978 $-0.4 \%$
Triadispora verrucata (SCHULZ, 1966) SCHEURING, 1970 - 1.2\%

Podosporites amicus SCHEURING, 1970 emend. SCHEURING, 1978

$$
-1.2 \%
$$

Brachysaccus neomundanus MÄDLER, 1964a - 3.8\%

Samaropollenites speciosus GOUBIN, 1965 - 3.8\%

Ovalipollis pseudoalatus (THIERGART, 1949) SCHUURMAN, 1976 $\mathbf{2 4 . 8 \%}$ (Fig. 7/8)

Staurosaccites quadrifidus DOLBY, 1976 in DOLBY \& BALME, 1976 $-\mathbf{1 . 8 \%}$ (Fig. 7/9)

Vitreisporites pallidus (REISSINGER, 1950) NILSSON, 1958 - 1.2\%

Alisporites opii DAUGHERTY, 1941 emend. JANSONIUS, 1971 $\mathbf{2 . 4 \%}$

Falcisporites stabilis BALME, $1970-\mathbf{0 . 8 \%}$

Sulcatisporites kraeuseli MÄDLER, 1964a - 1.8\%

Microcachryidites fastidioides (JANSONIUS, 1962) KLAUS, 1964 - 7.4\%

Haberkornia gudati SCHEURING, $1978-\mathbf{0 . 4 \%}$ (Fig. 7/10)

Haberkornia parva SCHEURING, $1978-\mathbf{0 . 4 \%}$

Praecirculina granifer (LESCHIK, 1955) KLAUS, 1960 - $\mathbf{0 . 6 \%}$

Partitisporites verrucosa (PRAEHAUSER-ENZENBERG, 1970) VAN DER EEM, $1983-\mathbf{0 . 8 \%}$

Duplicisporites granulatus LESCHIK, $1955-\mathbf{0 . 4 \%}$

Duplicisporites verrucosus LESCHIK, 1955 - 0.4\% (Fig. 7/11)

Camerosporites secatus LESCHIK, 1955 emend. SCHEURING, 1978 $-\mathbf{1 5 . 8 \%}$ (Fig. 7/12)

Ephedripites primus KLAUS, $1963-\mathbf{0 . 4 \%}$

Cycadopites follicularis WILSON \& WEBSTER, 1946 - $\mathbf{0 . 8 \%}$

Aulisporites astigmosus (LESCHIK, 1955) KLAUS, 1960 - 1.4\% (Fig. 7/13)

\section{Prasynophycean algae}

Leiosphaeridia sp. div. $-\mathbf{3 . 6 \%}$

\section{Acritarcha}

Veryhachium sp. $\mathbf{0 . 4 \%}$ (Fig. 7/14)

Micrhystridium sp. $-\mathbf{0 . 4 \%}$

Dictyotidium tenuiornatum EISENACK, 1955 - 1.2\%

Coenobial chlorophycean alga (Chlorococcales)

Plaesiodictyon mosellanum WILLE, 1970 - $\mathbf{0 . 2 \%}$

Botryococcus sp. $\mathbf{0 . 2 \%}$ 


\section{APPENDIX 2.}

\section{LIST OF REWORKED PERMIAN AND LOWER TRIASSIC PALYNOMORPHS FROM THE ŽALO UNIT CLAYSTONES}

(SAMPLE PAL-6, LOCATION 1 ON FIG. 2)

\section{Spores}

Cyclotriletes sp.

Endosporites papillatus JANSONIUS, 1962 (Fig. 7/17)

Densoisporites nejburgii (SCHULZ, 1964) BALME, 1970 (Fig. 7/16)

Lundbladispora sp.

Kraeuselisporites sp.

\section{Pollen}

cf. Nuskoisporites sp.

Limitisporites $\mathrm{sp}$.

cf. Lueckisporites virrkiae

\section{Acritarcha}

Micrhystridium sp.

\section{APPENDIX 3.}

\section{LIST OF PALYNOMORPH GROUPS ACCORDING TO THEIR BOTANICAL AFFINITY AND ECOLOGICAL SENSITIVITY}

A Leschikisporis aduncus

B Calamospora spp., Todisporites spp.

C Deltoidospora spp., Concavisporites spp.

D Osmundacidites spp., Verrucosisporites spp., Anapiculatisporites spp

E Uvaesporites spp., Sellaspora spp.

F Kyrtomisporis ervei

G Aratrisporites spp.

H Cycadopites spp., Aulisporites astigmosus, Ephedripites primus

I Porcellispora longdonensis

J Vitreisporites pallidus, Alisporites spp.,

K Brachysaccus neomundanus, Falcisporites stabilis, Sulcatisporites kraeuseli, Microcachryidites fastidioides, Podosporites amicus, Samaropollenites speciosus

L Ovalipollis pseudoalatus, Staurosaccites quadrifidus

M Infernopollenites spp., Lunatisporites spp., Striatoabieites spp.

N Triadispora spp.

O Heliosaccus dimorphus, Cannanoropollis scheuringii, Kuglerina meieri, Doubingerispora filamentosa

P Haberkornia gudati, Haberkornia parva, Praecirculina granifer, Partitisporites spp., Duplicisporites spp., Camerosporites secatus

Q Leiosphaeridia spp.,

$\boldsymbol{R} \quad$ Plaesiodictyon mosellanum, Botryococcus spp.

S Veryhachium spp., Micrhystridium spp., Dictyotidium tenuiornatum 